Article

\title{
Petrogenesis of the Snezhnoe Ruby Deposit, Central Pamir
}

\author{
Andrey K. Litvinenko ${ }^{1}$, Elena S. Sorokina ${ }^{2,3}$, Tobias Häger ${ }^{2, *}$, Yuri A. Kostitsyn ${ }^{3}$, \\ Roman E. Botcharnikov ${ }^{2}$, Alina V. Somsikova ${ }^{3}$, Thomas Ludwig ${ }^{4}$, Tatiana V. Romashova ${ }^{3}$ \\ and Wolfgang Hofmeister ${ }^{2}$ \\ 1 Department of Mineralogy and Gemology, Russian State Geological Prospecting University (MGRI), \\ Miklukho-Maklai str. 23, 117485 Moscow, Russia; litvinenkoak@mgri.ru \\ 2 Institut für Geowissenschaften, Johannes Gutenberg-Universität Mainz (JGU), J.-J.-Becher-Weg 21, \\ 55128 Mainz, Germany; esorokin@uni-mainz.de (E.S.S.); rbotchar@uni-mainz.de (R.E.B.); \\ hofmeister@uni-mainz.de (W.H.) \\ 3 Vernadsky Institute of Geochemistry and Analytical Chemistry, Russian Academy of Sciences (GEOKHI \\ RAS), Kosygin str. 19, 119991 Moscow, Russia; kostitsyn@geokhi.ru (Y.A.K.); somsikova@geokhi.ru (A.V.S.); \\ romashova@geokhi.ru (T.V.R.) \\ 4 Institut für Geowissenschaften, Universität Heidelberg, Im Neuenheimer Feld 234-236, 69120 Heidelberg, \\ Germany; thomas.ludwig@geow.uni-heidelberg.de \\ * Correspondence: haeger@uni-mainz.de
}

Received: 1 April 2020; Accepted: 22 May 2020; Published: 24 May 2020

Abstract: The Snezhnoe ruby deposit is located in the Muzkol-Rangkul anticlinorium within the Cimmerian zone of the Central Pamir. On the local scale, the deposit occurs on discrete relict bedding planes of calcitic marbles belonging to the Sarydzhilgin suite. Four ruby-bearing mineral assemblages are present within the main parts of the deposit: (1) scapolite + phlogopite + muscovite + margarite; (2) plagioclase + muscovite + margarite; (3) muscovite + phlogopite + margarite; (4) calcite. The ruby + calcite association is the most economically important, whereas the association of plagioclase + scapolite + phlogopite + muscovite is typical for the ruby-free parts of the deposit. Mica group minerals with a distinctive green color due to enhanced $\mathrm{Cr}$ and $\mathrm{V}$ concentrations are the main prospecting indicators for the ruby mineralization. The oxygen isotopic composition of the rubies is $+15.3 \%$, a common value for crustal metamorphic and sedimentary rocks. The ratios of indicative trace elements in the rubies are $\mathrm{Ga} / \mathrm{Mg}<8.2, \mathrm{Fe} / \mathrm{Mg}<51.2, \mathrm{Cr} / \mathrm{Ga}>6.9$ and $\mathrm{Fe} / \mathrm{Ti}<31.6$. These values are characteristic for metamorphic corundum. The bulk ruby-bearing rocks have an initial ${ }^{87} \mathrm{Sr} /{ }^{86} \mathrm{Sr}$ ratio of $\sim 0.70791$ and $\varepsilon \mathrm{Nd}$ of $\sim-9.6$, also pointing to the crustal origin of the deposit in agreement with the geological data. Ancient Al-enriched sediments are suggested to be a possible protolith for the ruby-bearing rocks. The temperature of the metamorphic processes was estimated at $760 \pm 30^{\circ} \mathrm{C}$ using Zr-in-rutile geothermometry. Raman mapping of rutile inclusions trapped within the ruby crystal indicates that the minimum pressure of mineralization was about one kilobar. The age determined by the $\mathrm{Rb}-\mathrm{Sr}$ thermal ionization mass spectrometry of phlogopite, plagioclase and bulk rock is $23 \pm 1.6 \mathrm{Ma}$, corresponding to the timing of relaxation after peak metamorphism during the Alpine-Himalayan Orogeny.

Keywords: ruby; mineralogical association; geochemistry; Snezhnoe deposit; Tajikistan; Central Pamir; Muzkol-Rangkul anticlinorium; in situ U-Pb LA-ICP-MS rutile dating; oxygen isotopes; $\mathrm{Rb}-\mathrm{Sr}$ and $\mathrm{Sm}-\mathrm{Nd}$ isotopes 


\section{Introduction}

Corundum $\left(\alpha-\mathrm{Al}_{2} \mathrm{O}_{3}\right)$ is the aluminum end-member of the hematite group of minerals and contains a limited number of transitional elements acting as its chromophores. Thus, ruby is assigned to the red-colored corundum variety that is due to the isomorphic substitution of $\mathrm{Al}^{3+}$ by $\mathrm{Cr}^{3+}$. Gem-quality ruby and sapphire (the blue-green-yellow-colored gem varieties of corundum) deposits are rare resulting in their high economic value with annual worldwide production exceeding several billion dollars [1]. The occasional discovery of large-scale commercial ruby deposits is related to the rarity of geological processes that produce them. Ruby mineralization commonly occurs as a result of moderate to high temperature metamorphic and magmatic processes in continent-continent collision zones ([2-6], etc.), less frequently in subduction areas [7]. Hence, their formation can be caused by several different processes over various timescales. This makes the reconstruction of the genesis and evolution of ruby mineralization challenging.

The Snezhnoe marble-hosted ruby deposit is located in the Tajik eastern part of the Central Pamir region within the Alpine-Himalayan Belt and is linked to Cenozoic Indo-Asia collision [4]. Due to being part of this collision, it shares many mineralogical and geochemical features common for metamorphic ruby sites formed along this mobile belt and related syn-tectonic structures including Mogok in Myanmar, Jegdalek in Afghanistan, the Hunza Valley in Pakistan, Luc Yen in Vietnam, etc. [4]. However, despite numerous studies ([8-12], etc.), the thermodynamic conditions during the mineralization process and the formation age of the ruby-bearing rocks of the Snezhnoe deposit remain poorly understood. New mineralogical and petrochemical features of the ruby-bearing rocks, along with data on the oxygen and radiogenic isotope signatures are presented in this study. This new dataset is then applied for a better understanding the geological processes responsible for the formation of the Snezhnoe ruby deposit as well as for the establishment of exploration criteria for discovering future gem corundum mineralization and deposits.

\section{Geological Setting}

On the regional scale, the Snezhnoe deposit is located within the Muzkol-Rangkul anticlinorium belonging to the eastern part of the Tajik Central Pamir region (Figure 1). The western part of the area is adjacent to the Vanch-Yazguliem anticlinorium. Both anticlinoria are linked to the exposed Precambrian crystalline basement which was tectonically re-worked during the Cimmerian Orogeny [13].

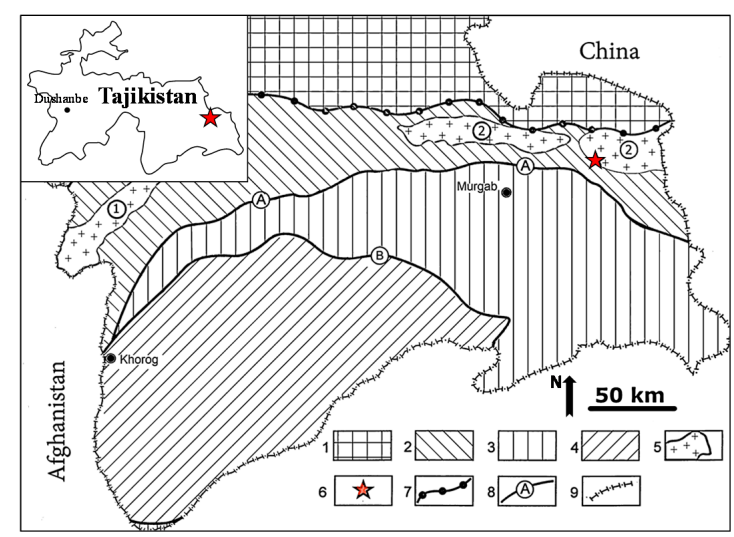

Figure 1. A location of the Snezhnoe deposit in relation to the main regional structures of the Pamir Mountains. Numbers 1-4 are folded regions: 1-northern Pamir (Hercynides); 2 to 4-southern Pamir (Cimmerian Plate). The southern Pamir is subdivided into zone 2-central Pamir, 3-south-eastern Pamir and 4-southwestern Pamir; 5-Early Proterozoic blocks, 6- Snezhnoe deposit; 7 and 8-major faults: 7-between folded regions (Vanch-Akbaytal) and 8-between tectonic zones: A-Rushan-Pshart and B-Gunt-Alichur; 9-border of Tajikistan; 1 (in circle) - Vanch-Yazgulem anticlinorium, 2 (in circle) -Muzkol-Rangkul anticlinorium. The map is modified after [13]. 
The Muskol-Rangkul anticlinorium consists of two tectonic blocks, the Sarymulin anticline in the west and the Shatput anticline in the east. In the central part, it is covered by Paleozoic-Mesozoic volcanic-sedimentary rocks. The Snezhnoe deposit is located on the southwestern flank of the Shatput block $[14,15]$. This block represents a steeply dipping monocline with the main foliation trending from $200^{\circ}$ to $230^{\circ}$ and a dip angle varying from $45^{\circ}$ to $70^{\circ}$. Its length is $\sim 15 \mathrm{~km}$ and the thickness is $\sim 1.5 \mathrm{~km}$. The monocline structure is adjacent to the Permian-Triassic system of the southeastern Pamir and the steeply dipping Muzkol fault (Figure 2).

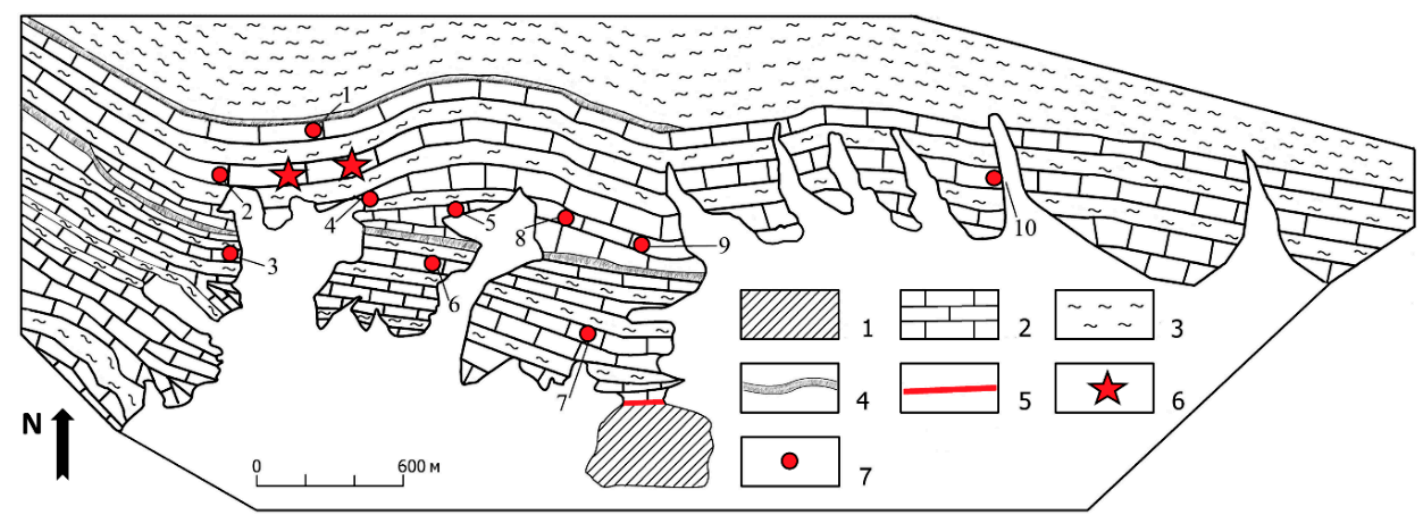

Figure 2. Geological map of the southwestern limb of the Shatput anticline modified after [8]. Geomorphologically, this is the southern slope of the Tura-Kuloma ridge. 1-Triassic system (lines indicate the strike of rocks; azimuth of dip is to the southeast). 2-4-Sarydzhilgin suite (sub-latitudinal strike): 2-marbles, 3-crystalline schists, 4-diopside-scapolite rocks, 5-deep fault, 6-ruby deposits: in the west-Nadezhda, in the east-Snezhnoye. 7-ruby occurrences close to red circles: 1-Timosha, 2-Corundum-4, 3-Corundum-7, 4-Lagernoye, 5-Alyonushka, 6-Corundum-2, 7-Corundum-1, 8-Corundum-8, 9-Corundum-6, 10-Trika. White area is the Quaternary sediments.

The thickness of the Muzkol metamorphic series within the Muzkol-Rangkul anticlinorium is about $6 \mathrm{~km}$. It consists of four suites [16], with the calcitic marbles of the Sarydzhilgin suite present as layers intercalated with amphibole-pyroxene and scapolite calciphyres, gneisses, crystalline schists and quartzites (Figure 3). These calcitic marbles host the Snezhnoe deposit, with the magnesium content of the marbles varying from $1.2 \% \mathrm{MgO}$ at the top to $2.7 \mathrm{wt} \% \mathrm{MgO}$ at the base. In the Snezhnoe deposit, micaceous ruby-bearing lenses are arranged as discrete en echelon lenses along the marble bedding surface and can be traced along strike for more than $200 \mathrm{~m}$ with the maximum thickness of individual lenses being $1 \mathrm{~m}$ [15]. These ruby-bearing lenses are cross-cut by numerous much smaller veins up to $5 \mathrm{~cm}$ thick and filled by later scapolite and mica group minerals, most likely linked to later hydrothermal processes [14]. The veins are zonal with the rim (up to $0.5 \mathrm{~cm}$ thick) composed of Cr-bearing muscovite and margarite and the core mainly comprising scapolite, which forms distinctive concentric aggregates.

The Muzkol series underwent multi-cyclic metamorphism from high-temperature amphibolite to epidote-amphibolite facies and then to retrogressive greenschist facies [16]. The first metamorphic cycle occurred at 1.9-1.6 Ga under the high-temperature conditions of amphibolite facies at $\mathrm{T}=700-750{ }^{\circ} \mathrm{C}$ and $\mathrm{P}=8-9 \mathrm{kbar}[16,17]$. The second cycle occurred between 100 to $20 \mathrm{Ma}$ and had a peak metamorphic temperature of about $800^{\circ} \mathrm{C}$ at a pressure close to $9 \mathrm{kbar}$ (with partial melting of protolith rocks) in the central part of the anticlinorium. The metamorphic facies evolved from high-temperature and high-pressure ones in the central part through medium T-P epidote-amphibolite to greenschist facies at $350^{\circ} \mathrm{C}$ and $4 \mathrm{kbar}$ towards the periphery $[18,19]$. 


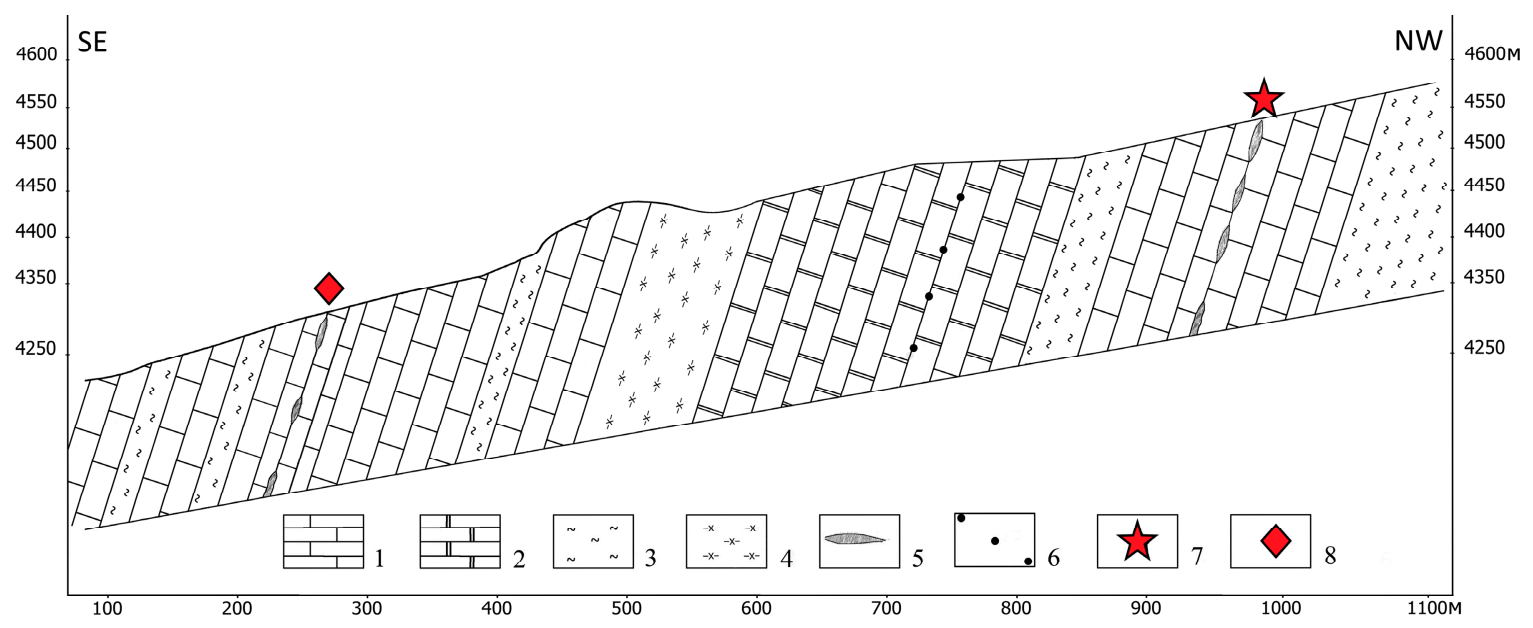

Figure 3. A geological cross-section of the upper part of the Sarydzhilgin suite through the Snezhnoe deposit and the ruby occurrences of Lagernoye and Alenushka: 1-calcitic marble and 2-dolomitic marble (dip angle is $60-70^{\circ}$ ), 3-high alumina crystalline schists, 4-diopside-scapolite rocks, 5-ruby deposits-micaceous lenses, 6-monomineralic ruby mineralization. 7-Snezhnoe deposit. 8-Alyonushka ruby occurrence. The cross-section is modified after [20]. The area above of the upper curve represents the modern topographic surface, whereas the white area below is the cutoff of the geological cross-section.

Since the last century, different types of prospecting, evaluation and exploration activity was carried out at the Snezhnoe deposit. Currently, mining activity is conducted from the surface and by underground methods.

\section{Materials and Methods}

During field trips in 2010-2017, the Snezhnoe deposit was traced along its strike in order to examine a complete profile along the ruby-bearing rocks (Table S1). The concentrations of major and trace elements in the ruby-bearing rocks were analyzed using X-ray fluorescence spectrometry. The paragenetic mineral associations with ruby were determined by petrographic studies. Minerals were studied in petrographic thin-sections and by X-ray diffraction (XRD), while their composition was measured using electron microprobe analysis (EMPA) and laser-ablation inductively coupled plasma-mass spectrometry (LA-ICP-MS). In situ U-Pb LA-ICP-MS analyses of rutile grains, syn-genetically associated with the ruby, were applied for geochronological reconstructions. Age determinations of bulk corundum-bearing rocks and mineral separates were conducted using thermo-ionization mass-spectrometry (TIMS). Oxygen isotope analyses of rubies using secondary ionization mass-spectrometry (SIMS) were done for identification of the possible protolith of the corundum-bearing rocks.

The whole-rock chemistry of the studied samples was determined using an AXIOS Advanced X-ray fluorescence spectrometer at the Vernadsky Institute of Geochemistry and Analytical Chemistry, Russian Academy of Sciences (GEOKHI RAS) with an X-ray tube equipped with a Rh anode, $3 \mathrm{~kW}$ power, a Soller scanning channel with the analyzing crystals and a detonating device.

The selected minerals extracted from the ruby-bearing rocks were identified by X-ray diffraction analysis using the DRON-3 M facility at the Russian State Geological Prospecting University. The X-ray source is a Co-anode using a Fe-filter with $30 \mathrm{kV}$ voltage, current of $30 \mathrm{~mA}$ and $2 \theta$ scanning angle from $5^{\circ}$ to $60^{\circ}$.

The mineral composition was determined by EMPA using a Cameca SX 100 in the wavelength-dispersive detection mode at the GEOKHI RAS with an electron beam of $15 \mathrm{kV}, 30 \mathrm{nA}$ and a beam size of $5 \mu \mathrm{m}$. A set of natural and synthetic reference materials was used for calibration. 
The detection limit for almost all elements was less than $0.01 \mathrm{wt} \%$. Elemental concentrations were calculated using the PAP correction (atomic number, fluorescence and absorption correction).

The LA-ICP-MS analysis was performed to determine the trace element concentrations within discrete zones of ruby grains from the Snezhnoe deposit using an ESI NWR193 ArF Excimer Laser combined with an Agilent 7500 ce quadrupole-ICP-MS at the Institut für Geowissenschaften, Johannes Gutenberg-Universität Mainz (JGU), Germany. The samples were ablated using a spot size of $70 \mu \mathrm{m}$, a repetition rate of $10 \mathrm{~Hz}$ and an energy density of approximately $3.0 \mathrm{~J} / \mathrm{cm}^{2}$. Warmup/background time was $15 \mathrm{~s}$, dwell time $30 \mathrm{~s}$ and wash out time $20 \mathrm{~s}$. Trace elements of interest within the ruby structure were analyzed using the following isotopes: ${ }^{24} \mathrm{Mg},{ }^{47} \mathrm{Ti},{ }^{51} \mathrm{~V},{ }^{53} \mathrm{Cr},{ }^{56} \mathrm{Fe}$ and ${ }^{69} \mathrm{Ga}$. The isotopes of additional elements ${ }^{6} \mathrm{Li},{ }^{9} \mathrm{Be},{ }^{23} \mathrm{Na},{ }^{24} \mathrm{Mg},{ }^{29} \mathrm{Si},{ }^{39} \mathrm{~K},{ }^{43} \mathrm{Ca},{ }^{47} \mathrm{Ti},{ }^{55} \mathrm{Mn},{ }^{86} \mathrm{Sr},{ }^{90} \mathrm{Zr},{ }^{93} \mathrm{Nb},{ }^{137} \mathrm{Ba}$, ${ }^{179} \mathrm{Hf},{ }^{181} \mathrm{Ta}$ and ${ }^{208} \mathrm{~Pb}$ were analyzed as well to exclude the areas with possible contamination from solid inclusions in time-resolved spectra. NIST (National Institute of Standards and Technology) SRM (standard reference material) 612 was used as primary reference material. NIST SRM 610 and basaltic USGS (United States Geological Survey) BCR-2G basalt glass were used as quality control materials. Reference and quality control materials were measured after every 30 corundum unknowns to monitor the accuracy and precision of the analyses and calibration. The time-resolved signal spectra were processed in GLITTER 4.4.1 software (www.glitter-gemoc.com, Macquarie University, Sydney, Australia) using ${ }^{27} \mathrm{Al}$ as the internal standard applying a theoretical value of $\mathrm{Al}_{2} \mathrm{O}_{3}$ as $100 \mathrm{wt} \%$ for the corundum samples and the values given in GeoReM database for the reference material [21,22]. The measured concentrations for most elements in both QCM agree within 18\% with the preferred values provided in the GeoReM database.

Trace-elements and $\mathrm{U}-\mathrm{Pb}$ isotopic composition of rutile grains and rutile inclusions within ruby were determined using the Element2 ICP-MS (ThermoFisher) coupled with an Analyte G2 193 nm excimer laser (PhotonMachines) at the Westfälische Wilhelms-Universität Münster. Twenty-three rutile grains from the Snezhnoe deposit were chosen for in situ LA-ICP-MS trace element measurements and U-Pb dating. Prior to analysis, backscattered electron images (BSE) were obtained at the Institut für Geowissenschaften, Johannes Gutenberg-Universität Mainz (JGU), Germany using a Zeiss DSM 962 SEM coupled with an Oxford energy-dispersive spectrometer. For LA-ICP-MS measurements, gas flow rates were about $1.1 \mathrm{~L} / \mathrm{min}$ for $\mathrm{He}, 0.9 \mathrm{~L} / \mathrm{min}$ and $1.1 \mathrm{~L} / \mathrm{min}$ for the Ar-auxiliary and sample gas. The cooling gas flow rate was set to $16 \mathrm{l} / \mathrm{min}$. Trace element concentrations within the rutile grains were determined by measuring the following isotopes: ${ }^{51} \mathrm{~V},{ }^{53} \mathrm{Cr},{ }^{90} \mathrm{Zr}{ }^{93} \mathrm{Nb},{ }^{95} \mathrm{Mo},{ }^{118} \mathrm{Sn},{ }^{121} \mathrm{Sb},{ }^{178} \mathrm{Hf}$, ${ }^{181} \mathrm{Ta},{ }^{182} \mathrm{~W},{ }^{208} \mathrm{~Pb},{ }^{232} \mathrm{Th}$ and ${ }^{238} \mathrm{U}$. The analysis of ${ }^{29} \mathrm{Si},{ }^{43} \mathrm{Ca},{ }^{49} \mathrm{Ti},{ }^{89} \mathrm{Y},{ }^{139} \mathrm{La}$ and ${ }^{140} \mathrm{Ce}$ was applied to control any possible contamination with intergrown minerals. The spot-size during the analyses was $70 \mu \mathrm{m}$ at a repetition rate of $10 \mathrm{~Hz}$ and an energy density of $3-4 \mathrm{~J} / \mathrm{cm}^{2}$. The background time was $15 \mathrm{~s}$, dwell time was $40 \mathrm{~s}$ and wash out time was $20 \mathrm{~s}$. The NIST SRM 612 was used as the reference material, while R10 [23] and R632 [24] were applied for quality control (QCM). The time-resolved spectra were processed in GLITTER 4.4.1 software using $\mathrm{Ti}$ as the internal standard applying the stoichiometric value of $\mathrm{TiO}_{2}$ as $100 \mathrm{wt}$ \% in pure crystalline rutile for analyzing the rutile unknowns.

For $\mathrm{U}-\mathrm{Pb}$ rutile dating, ${ }^{206} \mathrm{~Pb},{ }^{207} \mathrm{~Pb},{ }^{208} \mathrm{~Pb},{ }^{232} \mathrm{Th}$ and ${ }^{238} \mathrm{U}$ isotopes were measured. The repetition rate was $10 \mathrm{~Hz}$ using an energy of about $3 \mathrm{~J} / \mathrm{cm}^{2}$. The spots size of $70 \mu \mathrm{m}$ were ablated in close vicinity to the spots used for trace element measurements. Five unknowns were bracketed with three measurements on the R10 calibration material to correct for instrumental mass bias. The data reduction was performed using an in-house Excel spreadsheet [25]. The rutile reference material SP-1 (Adirondack

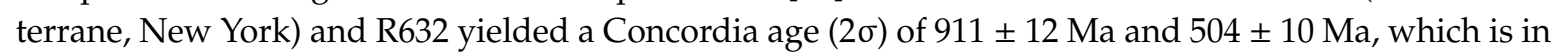
agreement with the ID-TIMS age of $911 \pm 2 \mathrm{Ma}$ and $496 \pm 2 \mathrm{Ma}$, respectively [24,26]. The Concordia diagrams and the age calculations were made using Isoplot v. 4.13 (Berkeley Geochronology Center, USA) [27].

Minimum entrapment pressures of rutile inclusions in the ruby host was estimated from the luminescence shift of the $\mathrm{Cr}^{3+} \mathrm{R}$-lines in the ruby host in close vicinity to the inclusions [28]. A Confocal Raman Spectrometer Horiba Jobin Yvon HR800 (HORIBA France SAS, Longjumeau, France) coupled 
with an Olympus BX41 microscope (Olympus Optical Co., Ltd., Tokyo, Japan) and automatic XYZ-stage were used for this technique. A red helium-neon laser with $\lambda=632.816 \mathrm{~nm}$ (polarized during the measurements) was used with a grating of 1800 grooves $/ \mathrm{mm}$. The confocal hole of $400 \mathrm{~mm}$ and the entrance slit of $100 \mathrm{~mm}$ produced a resolution of 0.7 (blue) to 0.5 (red) $\mathrm{cm}^{-1}$ for an exposition time of 0.5 $\mathrm{s}$ with measured steps of $100 \mathrm{~mm}$. Magnification of $\times 50$ was used for a measured range of $690.0-700.0$ $\mathrm{nm}$. The spectrometer was calibrated at $520.7 \mathrm{~cm}^{-1}$ using $\mathrm{Si}$ as a reference.

The oxygen isotope composition of the ruby grains from Snezhnoe was determined by using the Cameca IMS1280-HR ion microprobe at Heidelberg University (HIP), Germany. Before the SIMS measurements, BSE images were taken using a LEO 440 scanning electron microscope coupled with an Oxford Instruments X-Max energy dispersive spectrometer in order to avoid the areas with inclusions. A $2 \mathrm{nA}$ and $20 \mathrm{keV} \mathrm{Cs}^{+}$primary ion beam with a raster size of $10 \mu \mathrm{m}(12 \mu \mathrm{m}$ during pre-sputtering) was used for measurements targeting rim-to-rim areas of the ruby samples. Negative secondary ions were accelerated to $10 \mathrm{keV}$. The secondary ion image was limited to $\sim 23 \mu \mathrm{m}$, the dynamic transfer optical system (DTOS) was activated and sample charging was compensated with the electron gun (NEG). The ${ }^{16} \mathrm{O}$ and ${ }^{18} \mathrm{O}$ isotopes were detected simultaneously in two Faraday Cups. The mass resolving power was $\sim 2300$. Prior to each analysis, the secondary beam was centered automatically in the field aperture ( $\mathrm{X}$ and $\mathrm{Y})$ and the entrance slit ( $\mathrm{X}$ only). Including the time for beam centering, the analyses started after a total pre-sputtering time of $90 \mathrm{~s}$ and each analysis had 20 cycles with $4 \mathrm{~s}$ integration time per cycle. The internal precision reported is the standard deviation (SD) of the mean value of the isotope ratios. The baseline of the FC amplifiers was determined with an integration time of $200 \mathrm{~s}$. The instrumental mass fractionation was determined using a laser ruby reference material $\left(\delta^{18} \mathrm{O}=\right.$ $15.7 \% \pm 0.2 \%$, [29]) embedded within the same amount as the samples. The reproducibility of the IMF was $0.09 \%$ ( $1 \mathrm{SD}$ ) for the session with this sample.

Powders of bulk ruby-bearing rocks were produced for $\mathrm{Rb}-\mathrm{Sr}$ and $\mathrm{Sm}-\mathrm{Nd}$ isotope analyses. Additionally, single mineral fractions of plagioclase and phlogopite were selected for $\mathrm{Rb}-\mathrm{Sr}$ geochronology. Some $0.02-0.03 \mathrm{~g}$ of powder from a larger portion of 200-300 $\mathrm{g}$ was dissolved in a mixture of hydrofluoric and nitric acids with a 5:1 ratio on a shaker under incandescent lamps within three days. The obtained solutions were evaporated on a heating plate and, after evaporation, $1 \mathrm{~mL}$ of concentrated $\mathrm{HCl}$ acid was added three times to the dry residue. Rubidium, $\mathrm{Sr}$ and $\mathrm{Sm}+$ $\mathrm{Nd}$ mixtures were extracted from the solutions using fluoroplastic chromatographic columns with a DowexW $50 \times 8$ synthetic ion-exchange resin. The extraction was done by stepwise elution with 2.2 acid normality $(\mathrm{N})$ of $\mathrm{HCl}$ (for $\mathrm{Rb}$ and $\mathrm{Sr}$ ) and $4.0-\mathrm{N} \mathrm{HCl}$ (for the $\mathrm{Sm}+\mathrm{Nd}$ mixture). From the $\mathrm{Sm}+\mathrm{Nd}$ mixture, $\mathrm{Sm}$ and $\mathrm{Nd}$ were extracted by stepwise elution with $0.15-\mathrm{N} \mathrm{HCl}, 0.3-\mathrm{N} \mathrm{HCl}$ and $0.7-\mathrm{N} \mathrm{HCl}$ using polyethylene columns with synthetic ion-exchange Ln-spec resin. Measurements were done using a Finnigan ${ }^{\mathrm{TM}}$ Triton multi-collector thermal ionization mass spectrometer (TIMS) by Thermo Scientific at GEOKHI RAS using a two-tape (Re-Re) ion source for Rb, Sm and Nd and a single-tape (Re) ion source for Sr. Measurements were performed in a static mode with simultaneous recordings of ion currents for different isotopes. Normalization was carried-out according to the exponential law for ${ }^{86} \mathrm{Sr} /{ }^{88} \mathrm{Sr}=0.1194$ and ${ }^{148} \mathrm{Nd} /{ }^{144} \mathrm{Nd}=0.241572$ to eliminate mass-discrimination. The analyses of the international standards Sr-SRM-987 and JNdi-1 monitored the reproducibility and accuracy of isotope measurements for $\mathrm{Sr}$ and $\mathrm{Nd}$. The measured ratios in reference material are ${ }^{87} \mathrm{Sr} /{ }^{86} \mathrm{Sr}=0.710233 \pm 0.000010$ and ${ }^{143} \mathrm{Nd} /{ }^{144} \mathrm{Nd}=0.512093 \pm 0.000009$. Concentrations of $\mathrm{Rb}$, $\mathrm{Sr}, \mathrm{Sm}$ and $\mathrm{Nd}$ were determined by isotopic dilution using ${ }^{85} \mathrm{Rb}-{ }^{84} \mathrm{Sr}$ and ${ }^{149} \mathrm{Sm}-{ }^{150} \mathrm{Nd}$ tracers. The data-reduction was performed using an in-house Excel spreadsheet.

\section{Results}

\subsection{Petrology of the ruby-bearing rocks}

The ruby-bearing rocks vary significantly in terms of their mineral composition changing along both strike and depth. Their structure is characterized by a wide range of crystal sizes and shapes. 
There are four groups of mineral associations with ruby forming isolated areas in the deposit with one, three and four-mineral parageneses (Table 1): (1) scapolite (marialite) + phlogopite + muscovite + margarite; (2) plagioclase (albite-andesine) + muscovite + margarite (Figure 4A); (3) muscovite + phlogopite + margarite; (4) calcite (Figure 4B). Ruby-free areas of the deposit are characterized by plagioclase + scapolite + phlogopite + muscovite mineral paragenesis.

Table 1. List of major, minor and accessory minerals from the Snezhnoe deposit.

\begin{tabular}{|c|c|c|}
\hline Minerals/Mineral Class & Major and Minor Minerals (Methods Applied *) & Accessory Minerals (Methods Applied) \\
\hline Oxides & $\begin{array}{l}\text { Corundum (LA-ICP-MS geochemistry, SIMS oxygen } \\
\text { isotopy) }\end{array}$ & $\begin{array}{c}\text { Rutile (U-Pb LA-ICP-MS dating, } \\
\text { Raman mapping) } \\
\text { Ilmenite }+ \text { Nb-rich rutile } \\
\text { Magnetite }\end{array}$ \\
\hline Alumino-silicates & $\begin{array}{c}\text { Plagioclase (TIMS Rb-Sr/Sm-Nd isotopy) } \\
\text { Phlogopite (TIMS Rb-Sr/Sm-Nd isotopy) } \\
\text { Muscovite } \\
\text { Margarite }\end{array}$ & Corundophillite \\
\hline Silicates & Scapolite & $\begin{array}{c}\text { Zircon } \\
\text { Titanite } \\
\text { Tourmaline } \\
\text { Thorite } \\
\text { Dissakisite-(Ce) }\end{array}$ \\
\hline Carbonates & Calcite & $\begin{array}{l}\text { REE carbonates } \\
\text { Dolomite }\end{array}$ \\
\hline Sulfides & & $\begin{array}{c}\text { Pyrite } \\
\text { Pyrrhotite } \\
\text { Chalcopyrite }\end{array}$ \\
\hline Phosphates & & $\begin{array}{l}\text { Xenotime-(Y) } \\
\text { Monazite-(Ce) } \\
\text { Fluorapatite }\end{array}$ \\
\hline Native element & & Graphite \\
\hline
\end{tabular}

* EMPA was applied to all minerals listed.

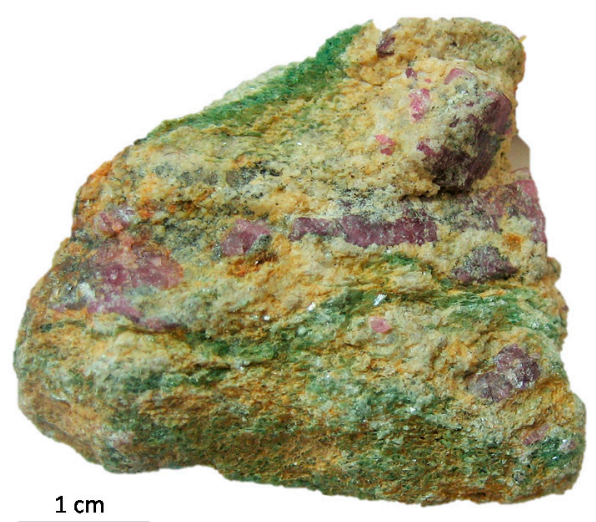

(A)

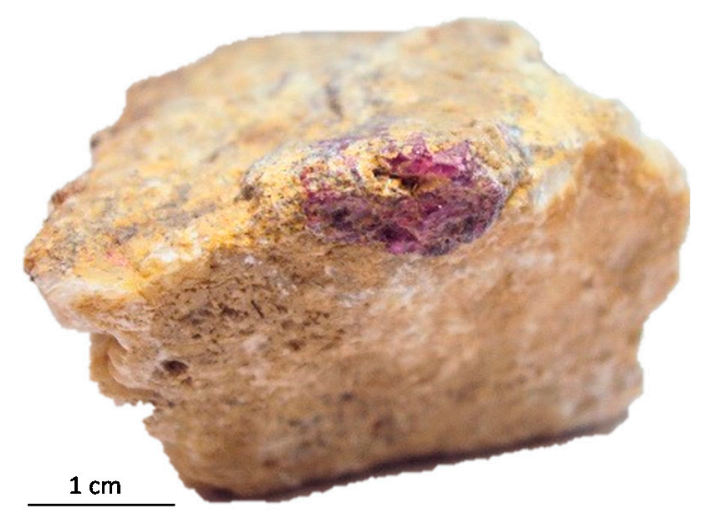

(B)

Figure 4. Images of hand specimens of Snezhnoe ruby-bearing rocks with: (A) ruby + plagioclase (albite-andesine) + muscovite (variety fuchsite) mineral paragenesis; (B) ruby + calcite mineral paragenesis. The images were modified from [11].

Gem-quality ruby is restricted in occurrence to $\mathrm{Cr}$-bearing mica lenses or graphite-free areas within the host marbles. The gem quality of ruby (i.e., degrees of transparency and color intensity) increases with decreasing number of associated paragenetic minerals. Therefore, the calcite mono-mineralic assemblage is the most economically valuable. 


\subsection{Mineralogy of Ruby-Bearing Rocks}

\subsubsection{Major and Minor Minerals}

Mica group minerals were found in most ruby associations. Micas often contain traces of $\mathrm{Cr}$ and V (Table 1, Tables S2-S4) resulting in their characteristic green color (Figure 4A). These green-colored mica group minerals serve as the main prospecting indicator for the ruby mineralization.

Muscovite forms small- to medium-sized flaky aggregates ranging from $\sim 1$ to $4 \mathrm{~mm}$. It is also found as inclusions in plagioclase and scapolite group minerals and in ruby (Figure 5, Table S2). It is rarely replaced by the chlorite group minerals, likely clinochlore containing up to $25.35 \mathrm{wt} \% \mathrm{SiO}_{2}$, $22.52 \mathrm{wt} \% \mathrm{Al}_{2} \mathrm{O}_{3}, 22.45 \mathrm{wt} \% \mathrm{FeO}, 13.98 \mathrm{wt} \% \mathrm{MgO}, 1.35 \mathrm{wt} \% \mathrm{Cr}_{2} \mathrm{O}_{3}$ [11] and forming thin films on the surface of muscovite or infilling fractures in corundum.

Fuchsite (the chromium-enriched variety of muscovite) is found in the form of a fine-medium flaky aggregates or individual flakes with size to 1-3 $\mathrm{mm}$. These aggregates form micaceous ruby-bearing lenses as well as rare impregnations in calcitic marbles. The fuchsites are characterized by high concentrations of $\mathrm{TiO}_{2}$ up to $4.78 \mathrm{wt} \%, \mathrm{MgO}$ up to $5.5 \mathrm{wt} \%, \mathrm{Na}_{2} \mathrm{O}$ up to $2.07 \mathrm{wt} \%, \mathrm{Cr}_{2} \mathrm{O}_{3}$ up to $2.5 \mathrm{wt} \%$, $\mathrm{V}_{2} \mathrm{O}_{3}$ up to $0.89 \mathrm{wt} \%$ and $\mathrm{F}$ from $0.03 \mathrm{wt} \%$ to $0.89 \mathrm{wt} \%$ (Table S2). Fuchsite crystals were also detected in cross-cutting veins, which were considered as hydrothermal in origin [14]. These minerals form concentrically zoned crystals with a diameter up to $6 \mathrm{~mm}$ and they are found in paragenetic association with later margarite flakes, concentric scapolite crystals and likely clinochlore. Rarely, the hydrothermal veins contain later tourmaline and quartz (never observed in the original ruby-bearing association).

Margarite (the Ca-end member of the brittle mica group) was detected as a syngenetic rock-forming mineral within the Snezhnoe deposit [11,14]. Margarite forms coarse- and finely flaked mineral grains. It is localized in occurrence mainly among calcite porphyroblasts and included within host corundum. The margarite contains $\mathrm{Na}_{2} \mathrm{O}$ from $1.24 \mathrm{wt} \%$ to $4.37 \mathrm{wt} \%, \mathrm{Cr}_{2} \mathrm{O}_{3}$ up to $1.27 \mathrm{wt} \%, \mathrm{~V}_{2} \mathrm{O}_{3}$ up to $0.1 \mathrm{wt} \%$ and F up to $0.32 \mathrm{wt} \%$ (Figure 5; Table S3).

Phlogopite forms lustrous brown-colored well-formed crystals some $2-5$ to $10 \mathrm{~mm}$ in size. It is enriched in $\mathrm{Cr}_{2} \mathrm{O}_{3}$ up to $3.20 \mathrm{wt} \%$ and $\mathrm{F}$ up to $1.87 \mathrm{wt} \%$ (Table S4). As in the case of muscovite, it is only rarely found to be replaced by chlorite group minerals.

Plagioclase forms white to black (due to the abundance of mineral inclusions including graphite, rutile, mica, zircon and rarely, ruby) prismatic crystals up to $10 \mathrm{~mm}$ in size. The composition is albite-andesine $\left(\mathrm{An}_{6-41}\right)$ (Table S5). Dufour et al. [9] noted anorthite in the paragenesis with phlogopite and muscovite, however, albite occurs within rims around the ruby grains.

Scapolite forms two generations: the early one is metamorphic in origin and syngenetic with ruby and associated minerals. For this generation, the meionite component ranges from $23 \mathrm{wt} \%$ to $74 \mathrm{wt} \%$, while chlorine varies from $0.01 \mathrm{wt} \%$ to $2.29 \mathrm{wt} \%$, sulfur content was up to $0.5 \mathrm{wt} \%$ and fluorine values were up to $0.25 \mathrm{wt} \%$ (Table S6). The later generation is hydrothermal in origin and occurs in veins cross-cutting the ruby-bearing rocks.

Calcite occurs within the micaceous lenses as irregular-shaped grains up to $0.4 \mathrm{~mm}$ and locally replaced by scapolite [11]. In the host marbles, it comprises the porphyroblastic rock matrix with crystal size varying from 1 to $6 \mathrm{~mm}$. 

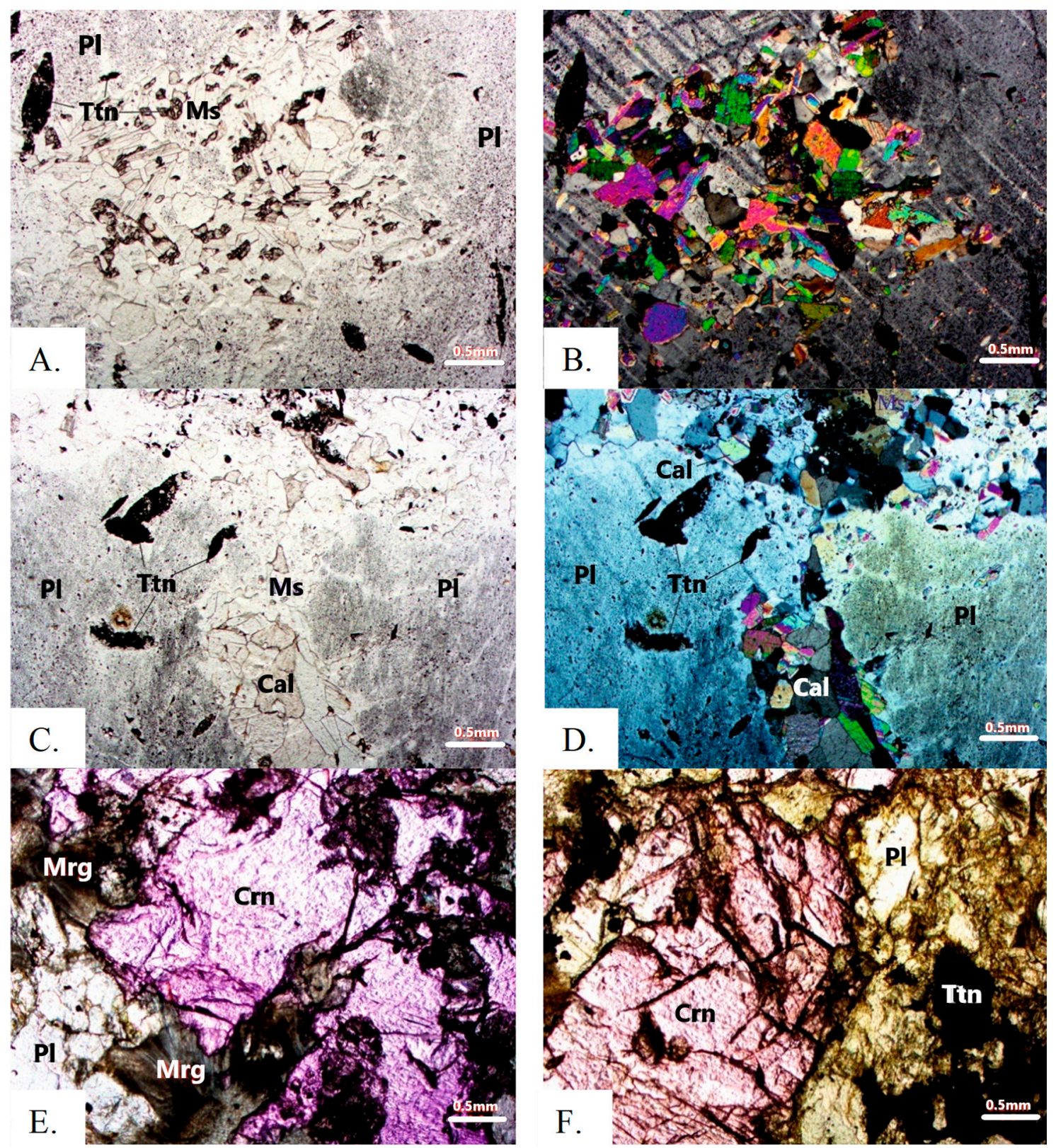

Figure 5. Petrographic thin-sections of titanite (Ttn), muscovite (Ms) and calcite (Cal) grains intergrown with larger plagioclase $(\mathrm{Pl})$ crystals in plane-polarized light $(\mathbf{A}, \mathbf{C})$ and under crossed-polarized light (B,D); corundum (Crn) intergrowths with margarite (Mrg) and plagioclase crystals (E,F), plane-polarized light.

\subsubsection{Accessory Minerals}

The accessory minerals identified in the studied ruby-bearing rocks are divided into two groups based on their typical size: (1) the large, up to millimeter size minerals, relatively easily distinguishable by eye and (2) those reaching only a few hundred micrometers in size and visible only under high magnification (Table 1). Currently, 20 accessory minerals were detected within the Snezhnoe deposit.

The first group includes graphite forming thin films around ruby grains, corundophyllite replacing muscovite, calcite with a minor $\mathrm{Mg}$ content, titanite (in 2 generations, with one replacing rutile and the other forming moderately rounded discrete crystals, Table S7), rutile (in 2 types with the earlier grains forming prisms and rounded grains linked to ruby and mica group minerals, while the later crystals replace titanite), tourmaline of the dravite-elbaite series (Table S9) and rare pyrite. 
The second group of accessory minerals was only detected at high magnification and includes ilmenite and $\mathrm{Nb}$-rich rutile, fluorapatite, pyrite, pyrrhotite, magnetite, chalcopyrite, thorite, dissakisite-(Ce) (allanite group), REE-rich carbonates, dolomite, xenotime-(Y), monazite-(Ce) and zircon containing up to $2 \mathrm{wt} \% \mathrm{HfO}_{2}$.

\subsubsection{Mineralogy, Geochemistry and Oxygen Isotopes of Ruby}

For the ruby-bearing assemblage, ruby is the largest mineral in these rocks with crystals reaching some $10 \times 20 \mathrm{~cm}$. Different ruby generations were observed during petrographic studies. The earlier crystals were found in the form of poikiloblastic grains in association with scapolite, plagioclase and micas. While the later generation of ruby was only observed in the calcitic marbles [30].

The ruby crystals are characterized by regular, distorted and combined forms. Regular crystal shapes are found in the form of hexagonal prisms combined with hexagonal pyramids, however, flattened by a pinacoid and rhombohedral faces (Figure 6). The crystal faces are often smooth and covered by fine-grained graphite, mica group minerals and calcite. Distorted crystals form sinuous and skeletal forms or nodules with a large number of faces poorly visible under the microscope. Combined crystals are formed by prisms complicated by skeletal surfaces. The surfaces of these crystals along with smooth ones, are tuberous, perforated (embossed) with noticeable resorption features. Margarite flakes of sometimes spherical shape, wedge-shaped titanite and calcite crystals are intergrown with the rubies.

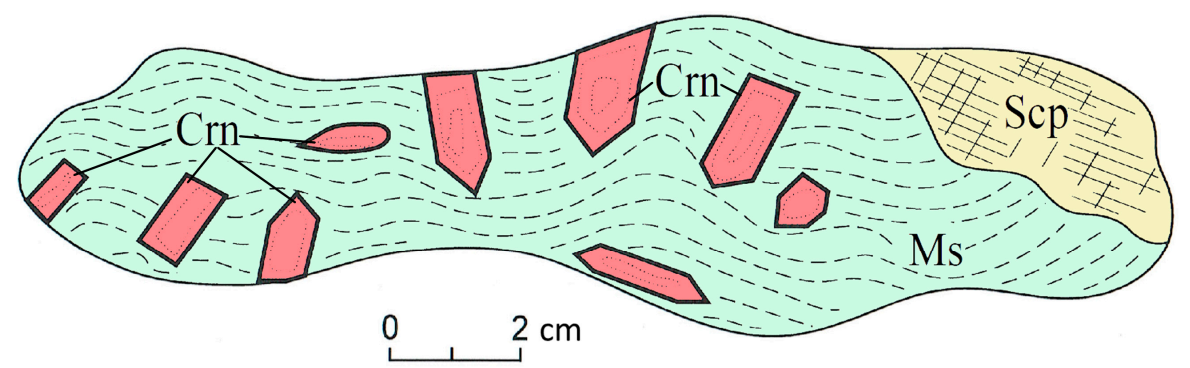

Figure 6. The sketch of a fragment of a ruby-bearing rock showing the apparent random orientation of ruby crystals. Crn—ruby crystals, Ms—muscovite (dashed lines), Scp—scapolite.

Using EMPA, the content of $\mathrm{Cr}_{2} \mathrm{O}_{3}$ within the pink corundum crystals varies from below detection limit (bdl; $<0.01 \mathrm{wt} \%$ ) to $0.24 \mathrm{wt} \%$. In the red grains, it reaches $1.5 \mathrm{wt} \%$ with a mean value of $0.3-0.6 \mathrm{wt} \%$. In fact, the variations in $\mathrm{Cr}^{3+}$ concentration within the ruby lattice are linked to the variety of ruby tones and shades at the Snezhnoe deposit [15], frequently expressed as oscillatory color zonation within some crystals. Moreover, the rubies also contain significant concentrations of other trace elements including $\mathrm{FeO}_{\mathrm{t}}$ up to $0.41 \mathrm{wt} \%$ and $\mathrm{V}_{2} \mathrm{O}_{3}$ up to $0.13 \mathrm{wt} \%$. The dark pink to red ruby crystals are characterized by $\mathrm{Cr}_{2} \mathrm{O}_{3}$ ranging from $0.01 \mathrm{wt} \%$ to $0.55 \mathrm{wt} \%, \mathrm{FeO}_{\mathrm{t}}$ ranging from $0.03 \mathrm{wt} \%$ to $0.19 \mathrm{wt} \%$, $\mathrm{TiO}_{2}$ values from $0.01 \mathrm{wt} \%$ to $0.17 \mathrm{wt} \%, \mathrm{MgO}$ from bdl ( $\left.<0.01 \mathrm{wt} \%\right)$ to $0.04 \mathrm{wt} \%$ and $\mathrm{V}_{2} \mathrm{O}_{3}$ from 0.01 $\mathrm{wt} \%$ to $0.07 \mathrm{wt} \%$ (Table S10).

Three gem-quality rubies with bright red color and purple hue from the Snezhnoe deposit were analyzed using LA-ICP-MS to determine their concentrations of $\mathrm{Cr}, \mathrm{Fe}, \mathrm{V}, \mathrm{Mg}$, Ti and Ga (Table S11). The obtained values are in good agreement with the EMPA analyses for similar colored ruby crystals. Chromium (512 to $4720 \mu \mathrm{g} / \mathrm{g})$, Fe (371-623 $\mu \mathrm{g} / \mathrm{g})$ and Ga $(65.9-98.1 \mu \mathrm{g} / \mathrm{g})$ all showed a heterogeneous distribution. However, these trace elements demonstrated a positive correlation between each other on different binary plots ( $\mathrm{Cr}+\mathrm{V}$ vs. Fe+ Ga, Fe vs. Ga, Cr vs. Ga, Figure 7). Such a correlation is linked presumably to the mechanism of $\mathrm{Al}^{3+}$ ion substitution within the corundum structure along the pinacoid faces in the direction perpendicular to the $c$-axis. It is frequently observed in other ruby locations [31]. The titanium content also shows a heterogeneous distribution ranging from 13.9 to $177 \mu \mathrm{g} / \mathrm{g}$ due to minor fluctuations, however, without any correlation with the $\mathrm{Cr}$, Ga or Fe values. 
Magnesium shows a mostly homogeneous distribution within the studied ruby grains (from 9.07 to $26.9 \mu \mathrm{g} / \mathrm{g})$.
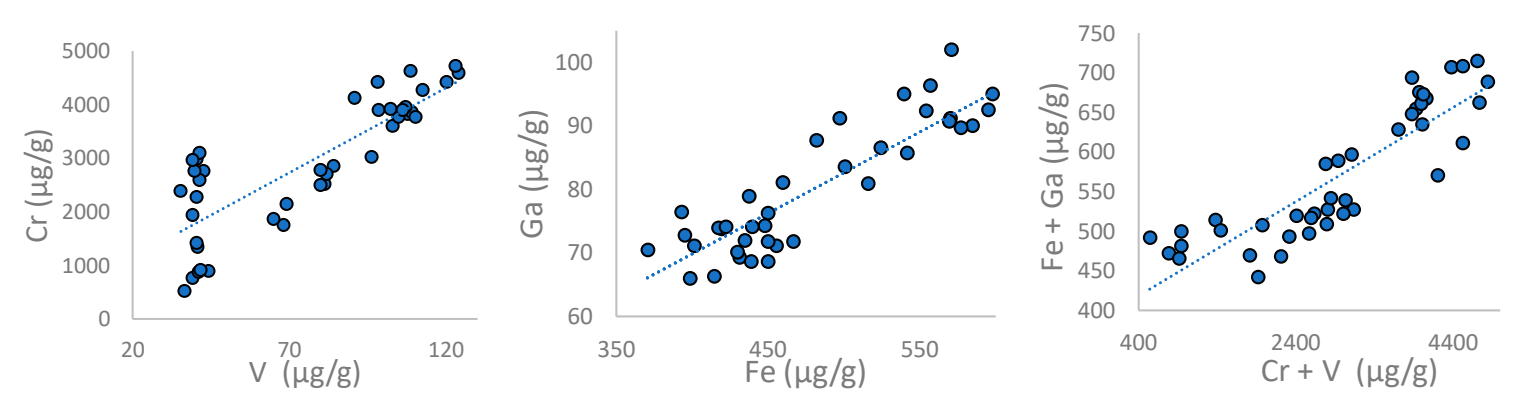

Figure 7. Trace element distribution within ruby grains oriented perpendicular to the $c$-axis on $\mathrm{Cr}$ vs.

V (left panel), Ga vs. Fe (middle panel) and Fe+Ga vs. Cr + V (right panel) binary plots.

The trace element ratios of $\mathrm{Ga} / \mathrm{Mg}<8.2, \mathrm{Fe} / \mathrm{Mg}<51.2, \mathrm{Cr} / \mathrm{Ga}>6.9$ and $\mathrm{Fe} / \mathrm{Ti}<31.6$ are all in the range common for metamorphic corundum [32,33]. On the $\mathrm{FeO}-\mathrm{Cr}_{2} \mathrm{O}_{3}-\mathrm{MgO}-\mathrm{V}_{2} \mathrm{O}_{3}$ vs. FeO $+\mathrm{TiO}_{2}+$ $\mathrm{Ga}_{2} \mathrm{O}_{3}$ plot [34], Snezhnoe rubies overlap the "John Saul ruby mine" area in the "ruby in marble" field in close proximity to the "metasomatic" corundum field (Figure 8).

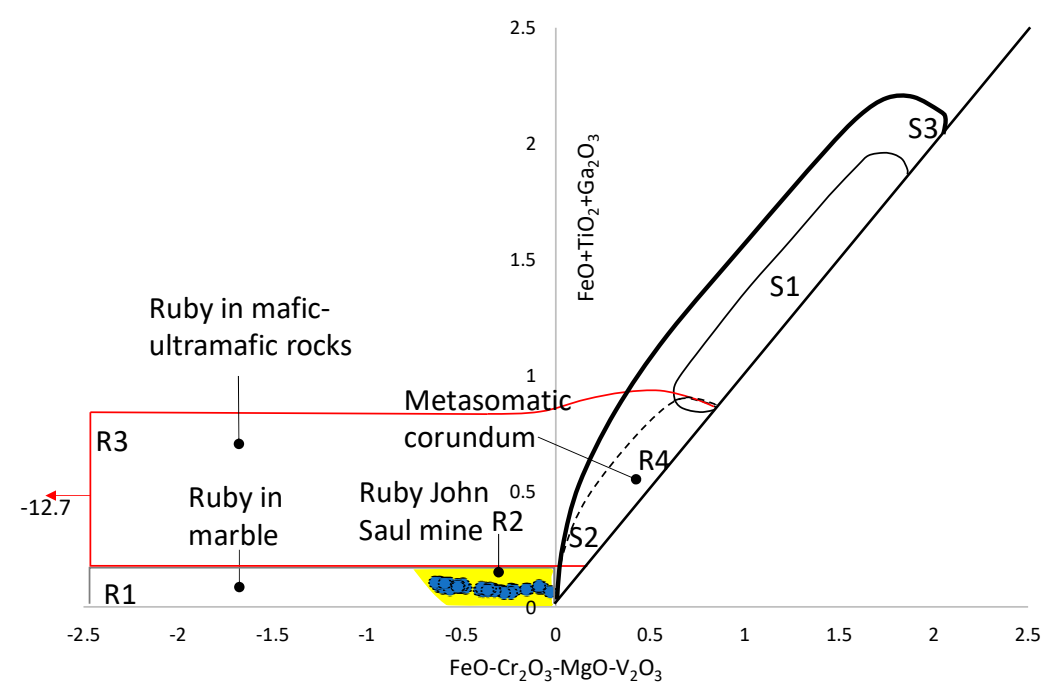

Figure 8. A FeO- $\mathrm{Cr}_{2} \mathrm{O}_{3}-\mathrm{MgO}-\mathrm{V}_{2} \mathrm{O}_{3}$ vs. $\mathrm{FeO}-\mathrm{TiO}_{2}-\mathrm{Ga}_{2} \mathrm{O}_{3}$ diagram (in wt \%) for rubies from the Snezhnoe deposit, modified after [34].

On the Cr/Ga vs. Fe/Ti discrimination diagram of [33], the Snezhnoe rubies clearly plot within the "metamorphic" field (Figure 9A). On the other hand, they are in the "transitional" and, partly, in the "magmatic" field on the Fe ( $\mathrm{gg} / \mathrm{g})$ vs. Fe/Ti plot of [32,33] (Figure 9B). 


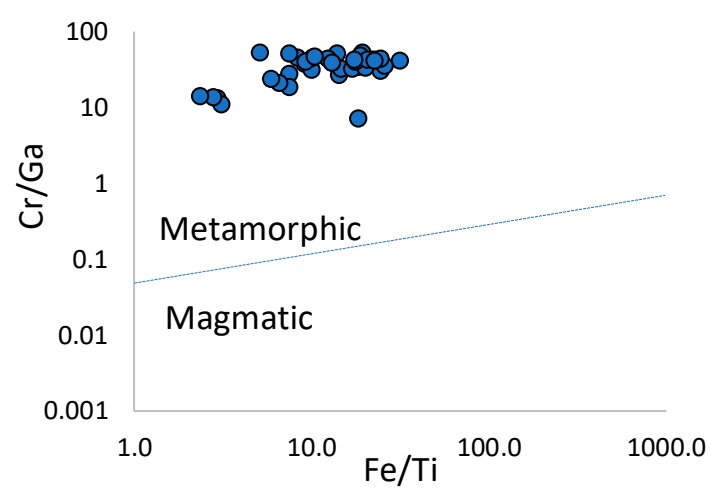

(A)

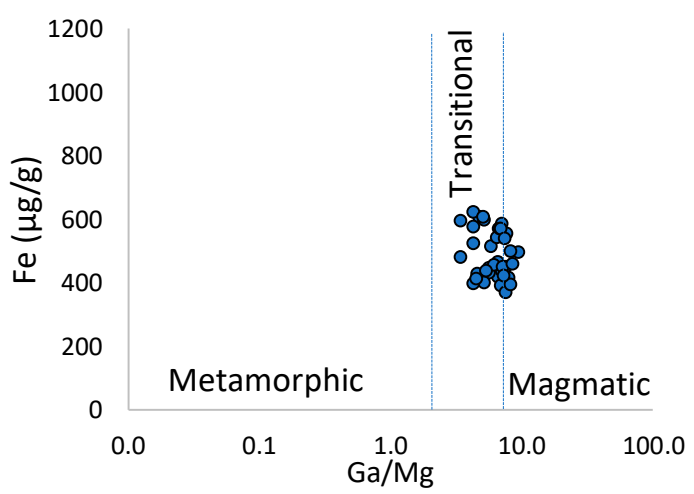

(B)

Figure 9. Cr/Ga vs. Fe/Ti plot of Snezhnoe ruby modified after [33] (A); Fe( $\mu \mathrm{g} / \mathrm{g})$ vs. Fe/Ti plot of Snezhnoe ruby modified after [32,33] (B).

The $\delta^{18} \mathrm{O}$ isotopic composition is used as a proxy in corundum provenance determination distinguishing corundum of different genetic origins [35]. Two ruby grains previously analyzed using LA-ICP-MS for their trace element composition were chosen for rim-to-rim oxygen isotope analysis using SIMS. In total, eight spots were measured within these samples. The $\delta^{18} \mathrm{O}$ rim-to-rim analyses show mostly a homogeneous distribution within the grains forming a narrow range from $+15.1 \%$ to $+15.3 \%$ with the standard deviation from $0.06 \%$ to $0.12 \%$ and the mean value of about $+15.25 \% \pm 0.07 \%$ o $(\mathrm{n}=8)$.

\subsection{Petrochemical Features of the Ruby-Bearing Rocks}

The whole-rock chemical composition of the ruby-bearing rocks varies considerably for all petrogenic elements (Table S12). These bulk-rock chemical variations correlate with changes in the mineral associations along strike.

Contents of the main petrogenic elements within the ruby-bearing rocks varied from $35 \mathrm{wt} \%$ to $98 \mathrm{wt} \%$ for $\mathrm{Al}_{2} \mathrm{O}_{3}$ (the most enriched in the Pamirs), up to $12 \mathrm{wt} \%$ for the sum of alkalis $\left(\mathrm{Na}_{2} \mathrm{O}+\right.$ $\mathrm{K}_{2} \mathrm{O}$ ) and from $3 \mathrm{wt} \%$ to $10 \mathrm{wt} \%$ for $\mathrm{CaO}$. In the crustal normalized spectra, the ruby-bearing rocks are mostly enriched in three+ and four+-charged, and, in less extend, one+, two + and five+-charged lithophile ions (Figure 10). However, they are slightly depleted in $\mathrm{Si}$ and $\mathrm{Mg}$. The ruby-bearing rocks are also characterized by the joint presence of oxides and sulfides of iron, along with traces of nickel up to $2 \mathrm{wt} \%$. All minerals found at the deposit contain $\mathrm{Cr}_{2} \mathrm{O}_{3}$ and $\mathrm{V}_{2} \mathrm{O}_{3}$ from hundredths to tenths parts of a percent, rarely, up to several percent. Cobalt and nickel were found in many minerals to hundredth parts of a percent. Minor elements within the ruby-bearing rocks exceed their average enrichment in the Earth's crust [36] by the orders of magnitude as follows: Ce (248), La (8.8), Ga (3.1), Sr (1.9), S (1.7), $\mathrm{Cl}$ (1.3) and $\mathrm{Zn}$ (1.3). The fluorine content is up to $4.6 \mathrm{wt} \%$ and this has played a significant role in increasing the mineral-forming activity of fluids. 


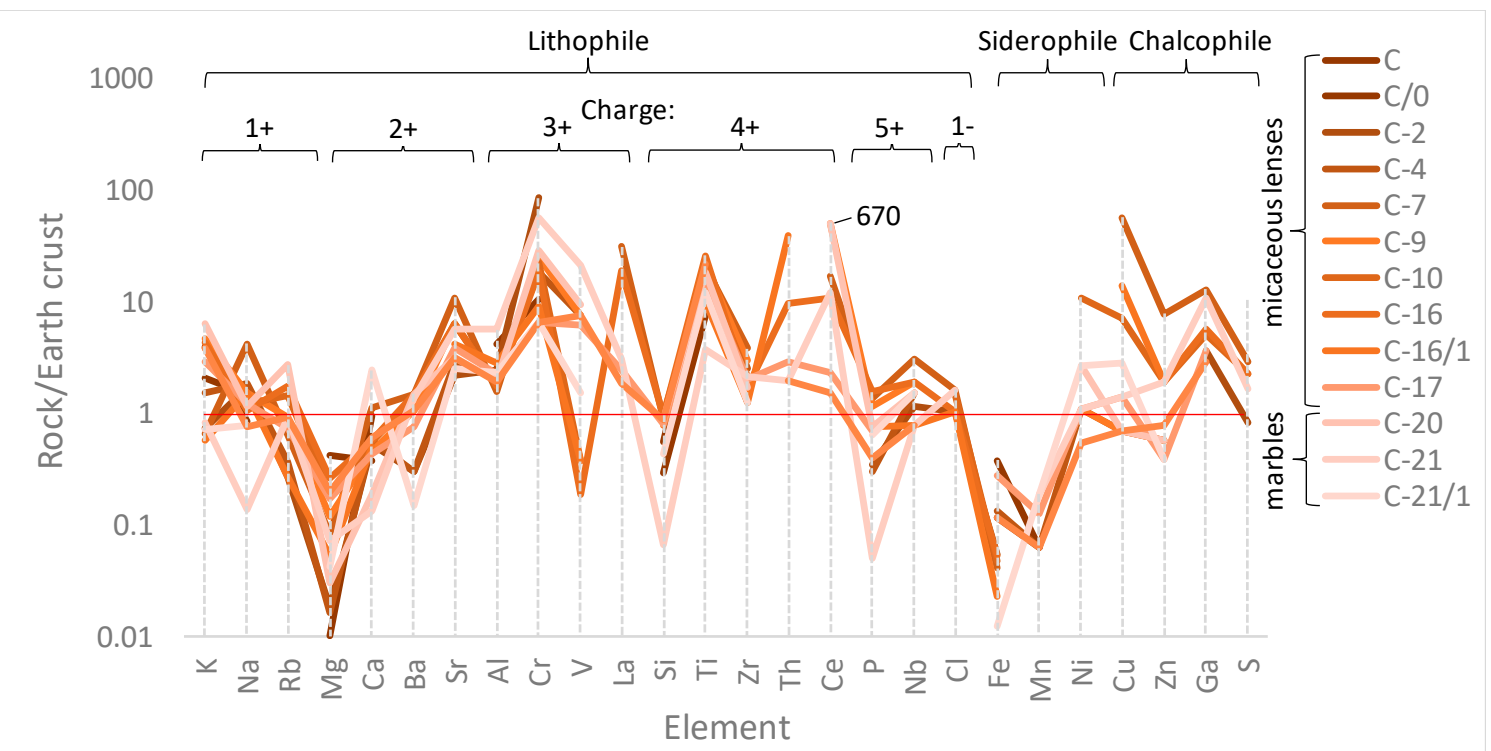

Figure 10. Crustal-normalized concentrations of lithophile (arranged by cation/anion charge), siderophile and chalcophile elements in the Snezhnoe deposit. The cerium ratio at 670 was cutoff. The values for the Earth's crust are from [36].

4.4. In Situ U-Pb LA-ICP-MS Rutile Dating, Zr-in-rutile Temperature and Raman Mapping of Rutile Inclusions

Rutile grains from the Sneznoe deposit varied from $200 \times 200 \mu \mathrm{m}$ to $600 \times 600 \mu \mathrm{m}$ in size with most showing a homogeneous composition. However, inclusions of apatite, Cr-bearing muscovite, margarite, zircon and calcite were found within rutile grains during SEM analyses. The following trace elements were detected in measured rutile grains (Table S13): V (1600-5000 $\mu \mathrm{g} / \mathrm{g}), \mathrm{Cr}(1360-5400$ $\mu \mathrm{g} / \mathrm{g}), \mathrm{Zr}(1570-2650 \mu \mathrm{g} / \mathrm{g}), \mathrm{Nb}(3000-6170 \mu \mathrm{g} / \mathrm{g}), \mathrm{Sn}(170-240 \mu \mathrm{g} / \mathrm{g}), \mathrm{Sb}$ (bdl-2.1), Hf (53-85 $\mu \mathrm{g} / \mathrm{g}), \mathrm{Ta}$ (210-400 $\mu \mathrm{g} / \mathrm{g}), \mathrm{W}(14-73 \mu \mathrm{g} / \mathrm{g}), \mathrm{Pb}(\mathrm{bdl}-68 \mu \mathrm{g} / \mathrm{g})$, Th (bdl-52 $\mu \mathrm{g} / \mathrm{g})$ and $\mathrm{U}(14-46 \mu \mathrm{g} / \mathrm{g})$. Molybdenum was measured but found to be below the detection limit (bdl varied from 0.3 to $0.9 \mu \mathrm{g} / \mathrm{g}$ ).

The in situ LA-ICP-MS U-Pb analyses of the rutile grains (21 spots) were plotted on Concordia diagram in Figure 11. All the rutiles analyzed yielded discordant ages with lower intercepts on the Concordia at about $12 \pm 1.5 \mathrm{Ma}(2 \sigma)$; MSWD (mean squared weighted deviation) is 9.7. The upper intercepts show an unreliable age at around 4.8-4.9 Ga likely due to contamination with common $\mathrm{Pb}$; the point with ${ }^{207} \mathrm{~Pb} /{ }^{208} \mathrm{~Pb}$ ratio is about 0.8 on the Tera-Wasserburg diagram (Figure 11, [37]). However, the ages obtained may be applied with caution due to the re-opening of the U-Pb system in rutile. 


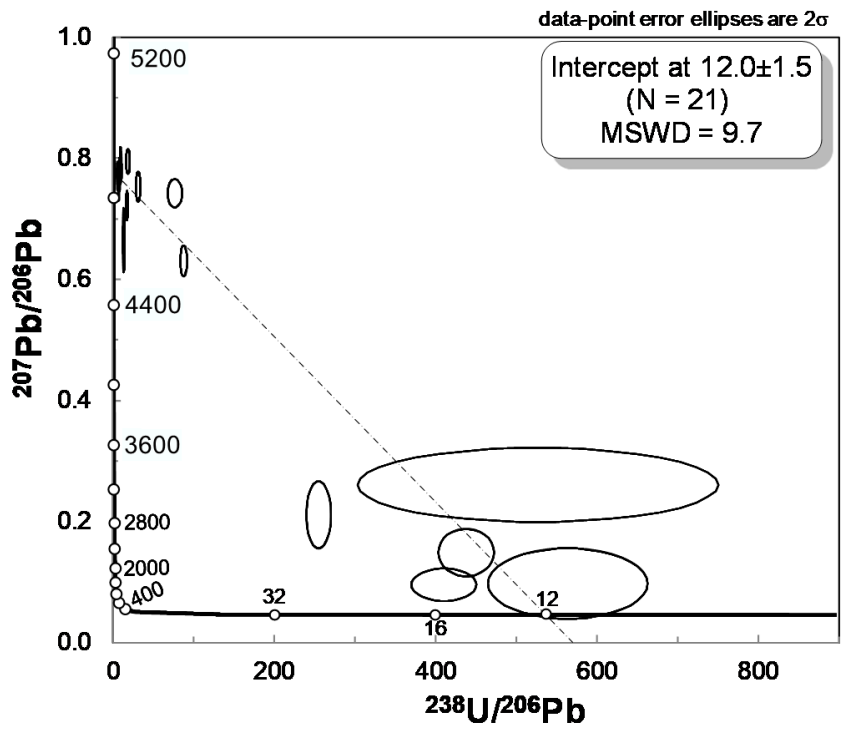

Figure 11. Tera-Wasserburg Concordia diagram based on the U-Pb LA-ICP-MS data for rutiles associated with ruby. The lower intercept age is shown in the legend.

Rutile grains were frequently found intergrown with zircon at the Snezhnoe deposit, and therefore could be used to calculate the apparent $\mathrm{Zr}$-in-rutile temperature [38]. The calculations were performed using the following formula: $\mathrm{T}\left({ }^{\circ} \mathrm{C}\right)=\frac{4470 \pm 120}{(7.36 \pm 0.10)-\log \left(\mathrm{Zr}, \frac{\mu g}{g}\right)}-273$ [39]. The obtained temperatures were in the range from $830 \pm 60^{\circ} \mathrm{C}$ (Table S13).

Laser-induced luminescence measurements were applied for two rutile inclusions trapped within ruby grains; the same sample containing other rutile inclusions was used for $\mathrm{U}-\mathrm{Pb}$ rutile dating. The rutile grains varied from about $10 \times 20 \mu \mathrm{m}$ to $10 \times 70 \mu \mathrm{m}$ in size. The Raman shift of $\mathrm{Cr}^{3+} \mathrm{R}$-lines in ruby photoluminescence spectra around rutile inclusions provided their minimum entrapment pressure at about 1-1.2 kbar (Figure 12) according to the calibration of [28].

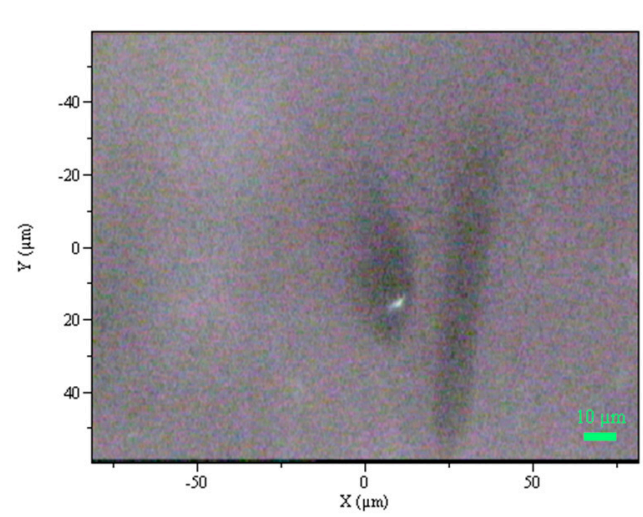

(A)

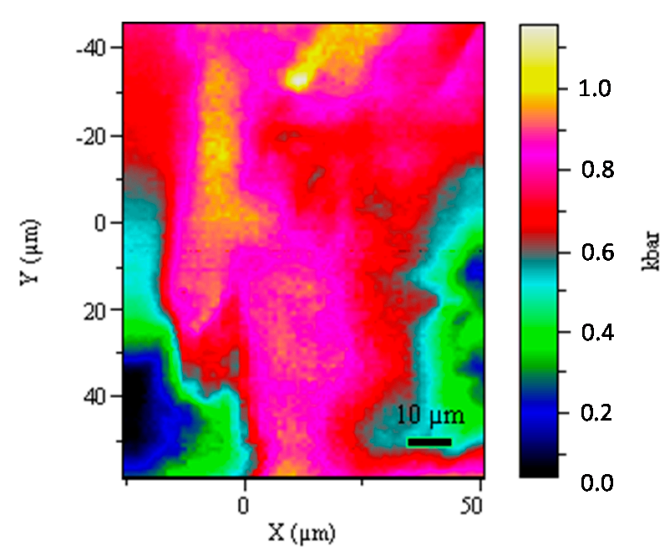

(B)

Figure 12. Photomicrograph of measured rutile inclusions within the ruby host (A); Raman map showing the shift of R-lines in laser-induced photoluminescence spectra expressed in pressure (in kbar) around rutile inclusions within the ruby host $(\mathbf{B})$.

\section{5. $\mathrm{Rb}-\mathrm{Sr}$ and $\mathrm{Sm}-\mathrm{Nd}$ Isotope Measurements}

The ruby-bearing schists from Snezhnoe were studied by TIMS in order to obtain their $\mathrm{Rb}-\mathrm{Sr}$ and $\mathrm{Sm}-\mathrm{Nd}$ isotope systematics. For the analyses, single minerals fractions of plagioclase and phlogopite were extracted from the rock matrix. The plagioclase and phlogopite contained no visual secondary 
alteration, however, some of the phlogopite could be possibly partially replaced by microscopic chlorite group minerals (most likely clinochlore). The results for the ruby-bearing schists within marble host rocks (single mineral fraction of mica and feldspar along with bulk rock analyzes) provided one errorchron (the large scatter in $\mathrm{Rb}-\mathrm{Sr}$ signatures defining significant \pm errors and MSWD) with an age at $23.0 \pm 1.6 \mathrm{Ma}$ (MSWD = 37; Figure 13) and an initial ${ }^{87} \mathrm{Sr} /{ }^{86} \mathrm{Sr}$ ratio of 0.70791 . The high MSWD value is likely linked to re-opening of the $\mathrm{Rb}-\mathrm{Sr}$ system in phlogopite. Thus, 3 phlogopite samples provided one errorchron with a younger age of $12 \pm 27 \mathrm{Ma}(\mathrm{MSWD}=14)$ and an initial ${ }^{87} \mathrm{Sr} /{ }^{86} \mathrm{Sr}$ ratio of 0.7085 .

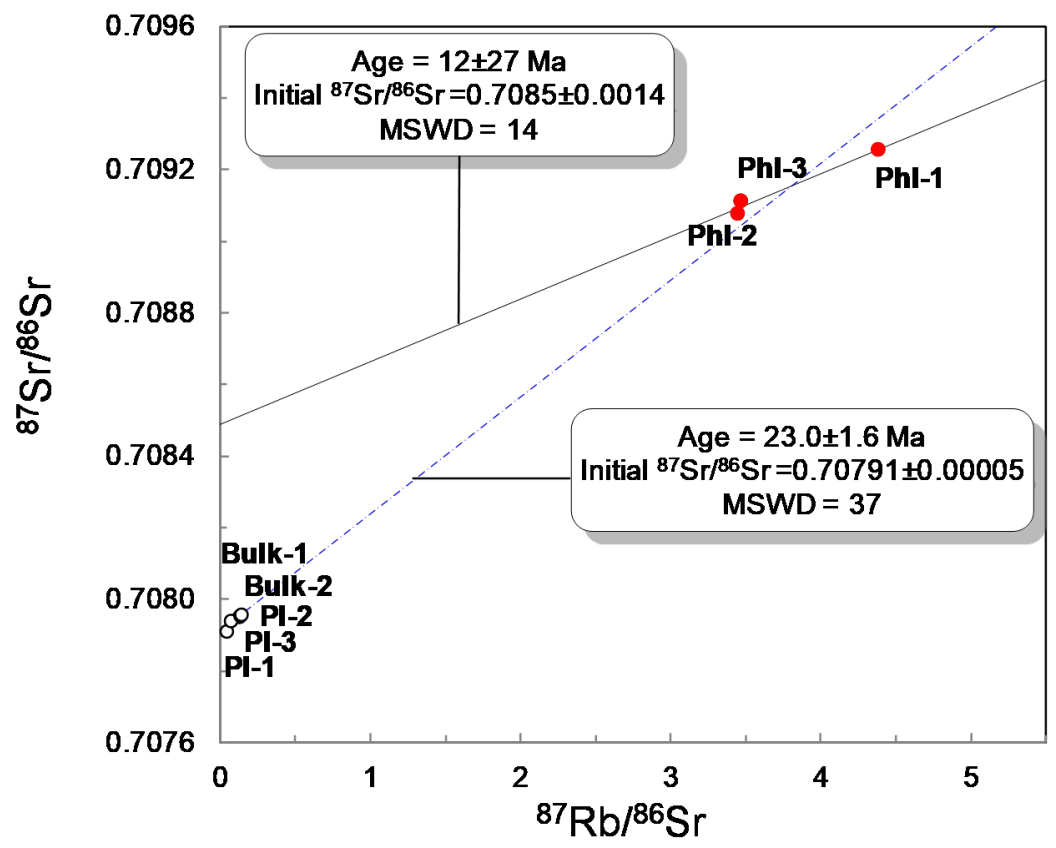

Figure 13. Two $\mathrm{Rb}-\mathrm{Sr}$ errorchrons showing the ages of ruby-bearing rock at Snezhnoe (blue dotted line), with a likely alteration process affecting the $\mathrm{Rb}-\mathrm{Sr}$ system in phlogopite (black solid line).

The epsilon notation value $\varepsilon \mathrm{Nd}_{(20 \mathrm{Ma})}$ for the bulk ruby-bearing rock was about -9.6 (Table S14).

\section{Discussion}

\subsection{Hypotheses of Origin of the Snezhnoe Ruby-Bearing Rocks}

Different hypotheses were proposed regarding the possible source for ruby-bearing rocks including metasomatic, hydrothermal or sedimentary-metamorphic scenarios. However, most of them remain controversial.

In the first scenario, Dufour et al. [9] proposed the formation of the ruby-bearing rocks through the metasomatic re-working of marbles intercalated with sandy-clay rocks, with the metasomatism induced likely by highly alkaline fluids. The desilication of sandy-clay rocks by fluids was followed by rapid enrichment in $\mathrm{Al}$ following the formation of biotite group minerals (according to our data, phlogopite) and muscovite. The $\mathrm{Al}_{2} \mathrm{O}_{3}$ excess resulted in the crystallization of corundum. This crystallization occurred during the final stage of regional metamorphism under the epidote-amphiboliteand greenschist facies with $\mathrm{T}=600-650{ }^{\circ} \mathrm{C}, \mathrm{P}=4-6 \mathrm{kbar}$ and $\mathrm{X}_{\mathrm{CO} 2}$ (mole fraction of $\left.\mathrm{CO}_{2}\right)=0.2-0.4$ (Figure 14). The timing of metamorphism, and, hence, ruby formation, corresponded to the Miocene (N1) during which the last recorded regional metamorphic process in the area occurred. Kievlenko [40] also referred to the ruby-bearing rocks in the Snezhnoe deposit to being of metasomatic origin and formed as endo-skarns due to the desilication of Al-Si rocks by hydrothermal solutions. The crystallization temperature of rubies was estimated at $450-500{ }^{\circ} \mathrm{C}$ by measuring the homogenization temperature of fluid inclusions inside the rubies. 
According to the second scenario [41], corundum mineralization formed by transport of $\mathrm{Si}, \mathrm{Al}, \mathrm{Ti}$, $\mathrm{Na}, \mathrm{Cl}$ and $\mathrm{B}$ in aqueous solutions migrated along fractures and layers in the marbles. Calcium and $\mathrm{CO}_{2}$ were removed by the fluid-marble interaction. Terekhov et al. [42] shared a similar opinion on ruby formation. These authors pointed out that the source of aluminum, required for ruby formation, may be linked to the endogenous fluids formed in an alkaline magmatic chamber of unknown location.

In the third scenario $[43,44]$, ruby and associated minerals within the marble host rocks were formed during metamorphic reworking of primary sedimentary rocks without significant involvement of any external material. This hypothesis was further developed by Litvinenko [45,46], Barnov [10] and Nasreddinov [12]. According to this scenario, ruby was formed during iso-chemical metamorphism of Proterozoic bauxite-like sediments hosted by limestone during amphibolite facies metamorphism. This scenario was further developed by Garnier et. al. [2], who pointed-out the significant role of evaporates hosted by marbles in the formation of ruby mineralization in several deposits located along the Alpine-Himalayan Belt. The source of elements required for their crystallization may be linked to the clay minerals. These clay minerals, hosted by the limestones, underwent the amphibolite facies metamorphism at $\mathrm{T}$ from 610 to $790^{\circ} \mathrm{C}$ and $\mathrm{P} \sim 6 \mathrm{kbar}$. Ruby mineralization occurred during the retrograde stage at $\mathrm{T}=620-670{ }^{\circ} \mathrm{C}$ and $\mathrm{P}=2.6-3.3 \mathrm{kbar}$.

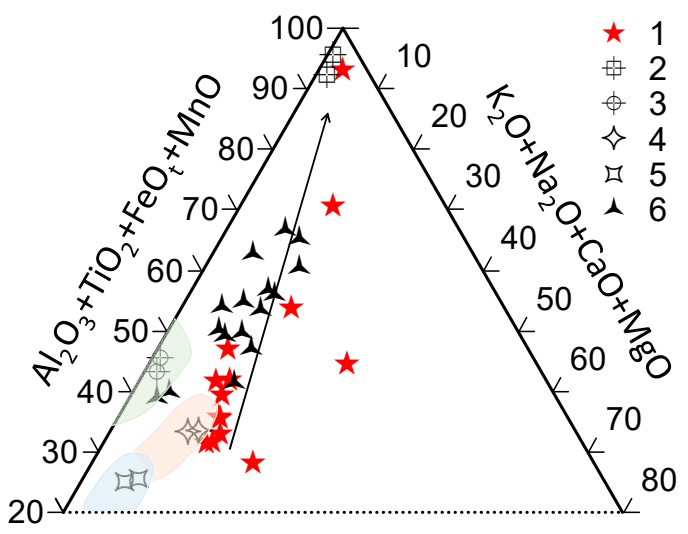

$\mathrm{SiO}_{2}$

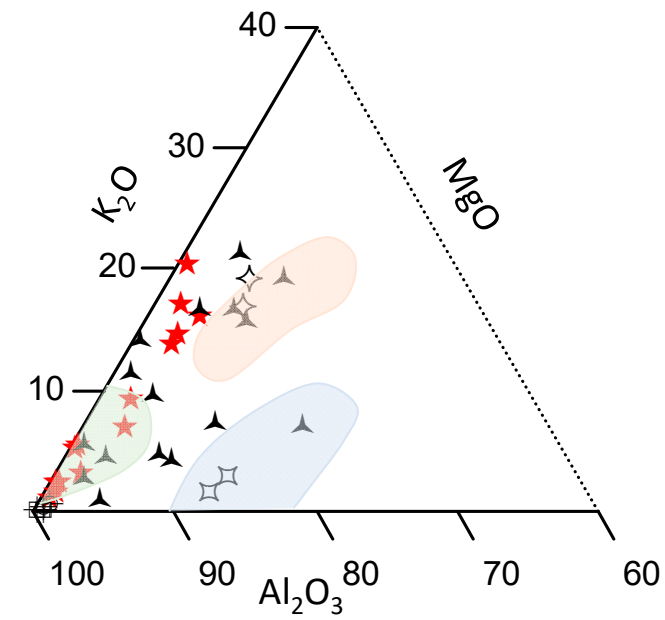

(B)

Figure 14. The $\mathrm{Al}_{2} \mathrm{O}_{3}+\mathrm{TiO}_{2}+\mathrm{FeOt}+\mathrm{MnO}-\mathrm{K}_{2} \mathrm{O}+\mathrm{Na}_{2} \mathrm{O}+\mathrm{CaO}+\mathrm{MgO}-\mathrm{SiO}_{2}(\mathbf{A})$ and $\mathrm{K}_{2} \mathrm{O}-\mathrm{MgO}-\mathrm{Al}_{2} \mathrm{O}_{3}(\mathbf{B})$ ternary diagrams with the data of Snezhnoe ruby-bearing rocks from this study-1; Precambrian pelitic sediments: bauxite ores -2 , kaolinitic clays -3 and green field, illitic clays -4 and orange field, montmorillonite clays -5 and blue field (numbers $2-5$ are the mean values of sediments after [47], the pelitic rock fields are after [48]); Al-enriched metamorphic rocks of Muzkol series-6 are after [49]. The rocks under numbers 2 and 3 overlap in the panel B.

\subsection{Origin of the Snezhnoe Ruby-Bearing Rocks}

The following geological characteristics indicate the sedimentary origin of the protolith considering the interlayered occurrence of carbonate and ruby-bearing rocks tracing along the strike on several kilometers. The petrochemical data reveal very high $\mathrm{Al}_{2} \mathrm{O}_{3}$ content ranging from $35 \mathrm{wt} \%$ to $98 \mathrm{wt} \%$ coupled with high alkali concentrations (about $12 \mathrm{wt} \%$ ) and a high proportion of $\mathrm{CaO}$ varying from 3 $\mathrm{wt} \%$ to $10 \mathrm{wt} \%$. The admixture of lithophile (Cr, V, Ti, U, etc.) and siderophile ( $\mathrm{Sn}, \mathrm{Ni}$, etc.) elements coupled with Ga contents to $180 \mu \mathrm{g} / \mathrm{g}$ and REE elements up to several thousand $\mu \mathrm{g} / \mathrm{g}$ common for sedimentary rocks (Table S8). On the $\mathrm{Al}_{2} \mathrm{O}_{3}+\mathrm{TiO}_{2}+\mathrm{FeOt}+\mathrm{MnO}-\mathrm{K}_{2} \mathrm{O}+\mathrm{Na}_{2} \mathrm{O}+\mathrm{CaO}+\mathrm{MgO}-\mathrm{SiO}_{2}$ ternary plot, the Shenzhoe ruby-bearing rocks overlap the fields of Precambrian illitic clays and bauxite ores with a distinct trend from the pelites toward the Al-enriched sediments (Figure 14). However, they are falling to illitic and kaolinitic clay fields in close proximity to lateritic bauxite values on $\mathrm{K}_{2} \mathrm{O}-\mathrm{MgO}-\mathrm{Al}_{2} \mathrm{O}_{3}$ diagram (Figure 14). 
The ruby geochemistry indicates a metamorphic origin with trace element ratios of $\mathrm{Ga} / \mathrm{Mg}<$ 8.2, $\mathrm{Fe} / \mathrm{Mg}<51.2, \mathrm{Cr} / \mathrm{Ga}>6.9$ and $\mathrm{Fe} / \mathrm{Ti}<31.6[32,33]$. On the $\mathrm{FeO}-\mathrm{Cr}_{2} \mathrm{O}_{3}-\mathrm{MgO}-\mathrm{V}_{2} \mathrm{O}_{3}$ vs. FeO + $\mathrm{TiO}_{2}+\mathrm{Ga}_{2} \mathrm{O}_{3}$ plot of [34], Snezhnoe rubies overlap the area of "John Saul ruby mine" (Kenia) in the "ruby in marble" field in close proximity to the "metasomatic" corundum field. Meanwhile, the John Saul mine rubies can clearly be separated in terms of their mineral inclusions (exsolved rutile needles, etc.), geochemistry (Ga values varies from $~ 160$ up to $480 \mu \mathrm{g} / \mathrm{g}$ [5]) and formation time (533 \pm 11 Ma by LA-ICP-MS U-Pb rutile dating [31]) from those of the Snezhnoe deposit. On the $\mathrm{Cr} / \mathrm{Ga}$ vs. Fe/Ti discriminant diagram of [33], the Snezhnoe rubies plot in the "metamorphic" field (Figure 9a). However, they are in the "transitional" and partly "magmatic" fields on the Fe( $\mu \mathrm{g} / \mathrm{g}) \mathrm{vs.}$ $\mathrm{Fe} / \mathrm{Ti}$ plot of $[32,33]$ (Figure 9b), which is unlikely due to the geological data and mineral assemblage of the ruby-bearing rocks. The ruby-oxygen isotope composition varied in the narrow range of $+15.25 \% \pm 0.07 \%$. In a closed system at a temperature of around $800{ }^{\circ} \mathrm{C}$ the resulting corundum oxygen isotopic composition is controlled mainly by the protolith $\delta^{18} \mathrm{O}$ values, however, it can also be buffered by the marble host rocks [50]. The obtained oxygen isotopic composition at $\sim 15.3 \%$ is slightly lower than that found in metamorphic marble-hosted corundums (from $+16.3 \%$ o to $+23.0 \%$; [ 4$]$ ). However, this is within the range detected for pelitic and bauxite-like sediments with $\delta^{18} \mathrm{O}$ values varying from about $+15 \%$ o to $+20 \%$ o [4,50]. Therefore, the obtained results confirm the third hypothesis indicating that the ruby-bearing rocks were formed from a sedimentary Al-enriched protolith re-worked during iso-chemical metamorphism.

According to the results of the Zr-in-rutile thermometer, the apparent crystallization temperatures were in the range of $830 \pm 60^{\circ} \mathrm{C}$. However, the application of this thermometer for rutiles crystallizing in the quartz-free environment with an unconstrained silicon activity $\left(\mathrm{a}_{\mathrm{SiO} 2}\right)$ may lead to significant temperature overestimation (up to $70^{\circ} \mathrm{C}$ at $750{ }^{\circ} \mathrm{C}$ [51]). Therefore, the apparent $\mathrm{Zr}$-in-rutile temperature should be recalculated to lower temperature of about $760 \pm 30^{\circ} \mathrm{C}$. This temperature estimation agrees with the range from 700 to $750{ }^{\circ} \mathrm{C}$ obtained in earlier studies [45] (Figure 15). Furthermore, this is close to the upper boundary of $600-650{ }^{\circ} \mathrm{C}$ detected previously by thermodynamic modeling of mineral equilibria in the system $\mathrm{CaO}-\mathrm{SiO} 2-\mathrm{A} 12 \mathrm{O} 3-\mathrm{Na} 2 \mathrm{O}-\mathrm{K} 2 \mathrm{O}$ [9], but well above the micro-thermometric estimates of $450-500{ }^{\circ} \mathrm{C}$ using fluid inclusions [40] (Figure 15). The Raman shift in the $\mathrm{Cr}^{3+} \mathrm{R}^{3}$ lines in ruby photoluminescence spectra targeted to areas around rutile inclusions resulted in estimates for the minimum pressure for rutile entrapment at about 1-1.2 kbar. Previous studies have suggested 4-6 kbar [9] and 8-9 kbar [45] required for the formation of ruby-bearing rocks (Figure 15). The lower pressures recorded by rutile entrapment in ruby could be caused by: (1) analysis of already decompressed areas due to the development of microscopic fractures in the ruby crystal or (2) measurement of the secondary rutile in such fractures formed by a replacement of the titanite inclusions originally trapped within the ruby host. 


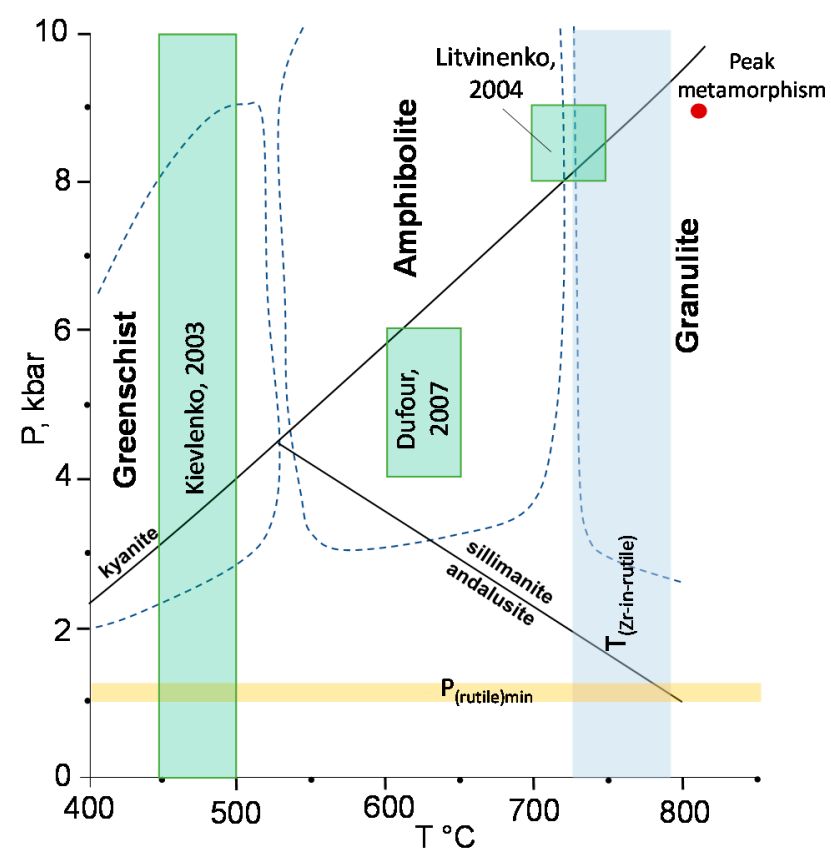

Figure 15. Temperature vs. pressure binary plot showing formation conditions of Snezhnoe ruby deposit recorded in rutiles: $\mathrm{Zr}$-in-rutile thermometer $\mathrm{T}_{(\mathrm{Zr} \text {-in-rutile) }}$ (blue vertical field) and Raman mapping

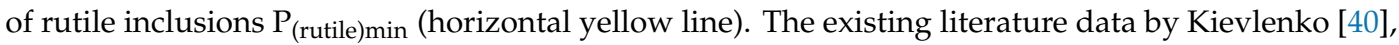
Dufour [9] and Litvinenko [44,45] are shown as green fields. The peak metamorphism conditions are shown as red point after $[18,19]$. The stability fields of aluminosilicates (divided by black lines) are after [52]. Schematic fields of Greenschist, Amphibolite and Granulite metamorphic facies are shown for clarity.

The $\mathrm{Rb}-\mathrm{Sr}$ isotopic measurements showed one errorchron with an age of $23 \pm 1.6 \mathrm{Ma}$. However, these data should be used with caution due to the upper values in samples of phlogopite with different degrees of alteration to clinochlore. The phlogopite errorchron (Figure 13) as in the case for the lower intercept on the U-Pb Concordia (U-Pb rutile analyses in Figure 11) showed younger ages at about ca. $12 \mathrm{Ma}$ falling well within the range of 7-17 Ma obtained previously during K/Ar muscovite dating [41]. This phenomenon suggests the re-opening of the $\mathrm{Rb}-\mathrm{Sr}$ and $\mathrm{K} / \mathrm{Ar}$ systems in mica group minerals along with $\mathrm{U}-\mathrm{Pb}$ systematics in rutile linked likely to later hydrothermal process occurring at the deposit. This hydrothermal process led to the formation of several centimeter-thick veins filled with scapolite and mica group minerals clearly cross-cutting the ruby-bearing rocks. Meanwhile, these obtained $\mathrm{Rb}-\mathrm{Sr}$ and $\mathrm{U}-\mathrm{Pb}$ rutile ages are close to the Dufour et al. [9] estimations, while nowhere near the Budanova [19] observations suggesting a Precambrian age. These $\mathrm{Rb}-\mathrm{Sr}$ ages are likely linked to the cooling stage and the period of relaxation after peak metamorphism during the Alpine-Himalayan Orogeny. However, they also fall in the time range for the other marble-hosted corundum deposits within this major tectonic structure [2,53] (Figure 16). The modeled age of the protolith $\mathrm{T}(\mathrm{DM})$ - model age — was estimated at about $1.3 \mathrm{Ga}$, later than the timing of the first metamorphic cycle in the area of the Snezhnoe deposit (1.9-1.6 Ga). However, this still confirms the hypothesis of a Proterozoic protolith for the ruby-bearing rocks. 


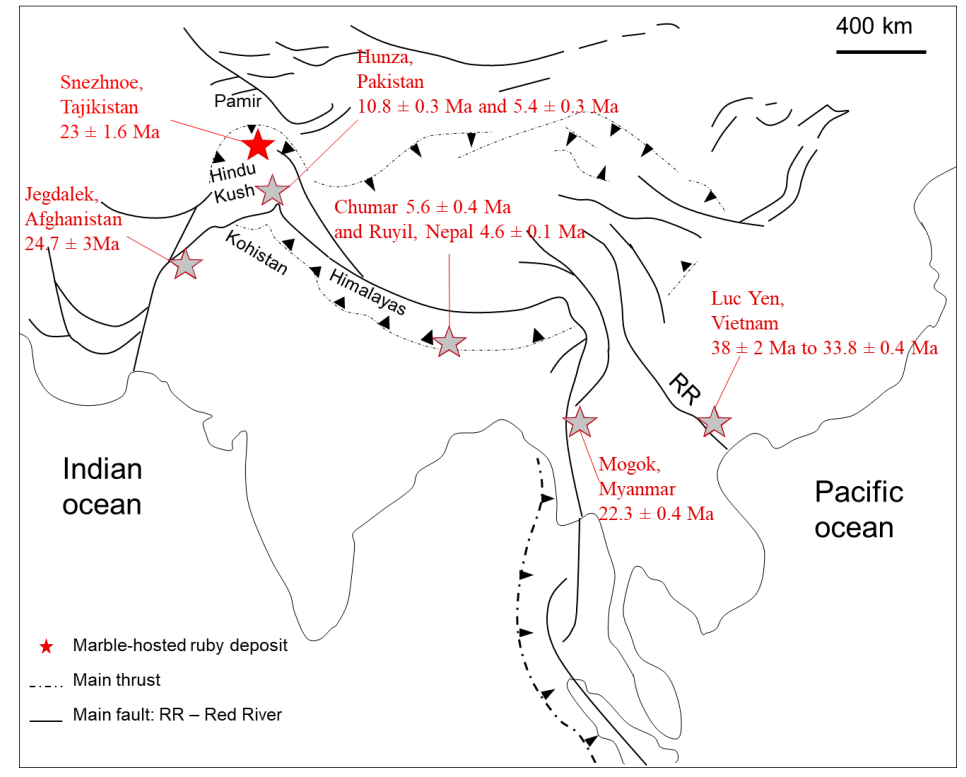

Figure 16. Tectonic map of Central and South East Asia with location of marble-hosted gem corundum deposits shown as gray stars (modified after [54]). Red star indicates the Snezhnoe ruby deposit with $\mathrm{Rb}-\mathrm{Sr}$ age obtained in this study. The ages of ruby deposits are from $[2,53]$.

\section{Conclusions}

1. The regional position of the Snezhnoe deposit is localized by the Muzkol-Rangkul anticlinorium within the Cimmerian zone of the Central Pamir. This tectonic structure comprises Precambrian metamorphic and igneous rocks that have undergone multi-stage metamorphism (1) under high-temperature amphibolite facies conditions (Precambrian) and, then, (2) from the melting zone in the central part of the anticlinorium through epidote-amphibolite to greenschist facies in the periphery (Mesozoic-Cenozoic). Ruby and associated minerals from the Snezhnoe deposit most likely formed at temperatures of $760 \pm 30^{\circ} \mathrm{C}$. The minimum pressure for rutile entrapment was estimated at $\sim 1-1.2$ kbar. The $\mathrm{Rb}-\mathrm{Sr}$ errorchron age (phlogopite—plagioclase-bulk rock) yielded $23 \pm 1.6 \mathrm{Ma}$. However, the Rb-Sr systematics of the phlogopite was likely affected by later hydrothermal processes at Snezhnoe. Therefore, the Rb-Sr errorchron age for the ruby-bearing rocks should be used with caution.

2. The ratios of chromophore trace elements within Snezhnoe ruby are $\mathrm{Ga} / \mathrm{Mg}<8.2, \mathrm{Fe} / \mathrm{Mg}$ $<51.2, \mathrm{Cr} / \mathrm{Ga}>6.9$ and $\mathrm{Fe} / \mathrm{Ti}<31.6$, all within the range for metamorphic corundum. On the $\mathrm{FeO}-\mathrm{Cr}_{2} \mathrm{O}_{3}-\mathrm{MgO}-\mathrm{V}_{2} \mathrm{O}_{3}$ vs. $\mathrm{FeO}+\mathrm{TiO}_{2}+\mathrm{Ga}_{2} \mathrm{O}_{3}$ plot, the Snezhnoe rubies overlap those of the "John Saul ruby mine" in the "ruby in marble" field. On the $\mathrm{Cr} / \mathrm{Ga}$ vs. Fe/Ti discriminant diagram, the Snezhnoe rubies plot within the "metamorphic" field. The ruby-oxygen isotope composition is consistently around $+15.25 \% \pm 0.07 \%$ well within the field for metamorphic and sedimentary rocks. The initial ${ }^{87} \mathrm{Sr} /{ }^{86} \mathrm{Sr}$ ratio is about 0.70791 and $\varepsilon \mathrm{Nd}$ is about -9.6 for bulk corundum-bearing rocks, confirming the geological data on the crustal origin of the ruby-bearing rocks at Snezhnoe. The possible protolith for these rocks was Proterozoic pelitic or bauxite-like sediments intercalated with carbonates.

3. The chemical composition of the ruby-bearing rocks varies considerably in terms of petrogenetic elements and is linked to the varying mineral associations along strike. Four mineral associations are distinguished: (1) ruby + scapolite (marialite) + muscovite + margarite + phlogopite; (2) ruby + plagioclase (albite-andesine) + muscovite + margarite; (3) ruby + muscovite + phlogopite + margarite; (4) ruby + calcite. The fourth mineral association is the most economically valuable. Meanwhile, the association of plagioclase + scapolite + phlogopite + muscovite is characteristic of the ruby-free zones. Mica group minerals were found in most ruby associations. Their specific features are traces of $\mathrm{Cr}$ and $\mathrm{V}$ linked to their green color being the main prospecting indicator for the ruby mineralization. 
Supplementary Materials: The following are available online at http://www.mdpi.com/2075-163X/10/5/478/s1, Table S1: Description of the ruby-bearing samples used in this study; Table S2: Chemistry of muscovite (no. 1-4) chromium-bearing muscovite (no. 5-20) and fuchsite (no. 21-23); Table S3: Chemistry of margarite; Table S4: Chemistry of phlogopite; Table S5: Chemistry of plagioclase group minerals; Table S6: Chemistry of scapolite group minerals; Table S7: Chemistry of titanite; Table S8: Chemistry of rutile; Table S9: Chemistry of tourmaline group minerals; Table S10: Chemistry of corundum using EMPA (in wt.\%); Table S11: Chemistry of corundum obtained by LA-ICP-MS (in $\mu \mathrm{g} / \mathrm{g}$ ); Table S12: Chemistry of ruby-bearing samples (wt.\%); Table S13: Geochemistry of rutile grains used for in situ U-Pb LA-ICP-MS geochronology; Table S14: Rb-Sr and Sm-Nd isotope measurements of phlogopite, plagioclase and ruby-bearing rock from the Snezhnoe deposit.

Author Contributions: Conceptualization, A.K.L. and E.S.S.; methodology, T.H., E.S.S., Y.A.K. and T.L.; formal analysis, A.K.L., E.S.S., T.H., A.V.S., T.L. and T.V.R.; investigation, A.K.L. and E.S.S.; writing一original draft preparation, A.K.L. and E.S.S.; writing-review and editing, E.S.S., T.H., R.E.B., Y.A.K., A.V.S. and W.H.; supervision, R.E.B. and W.H.; funding acquisition, E.S.S. All authors have read and agreed to the published version of the manuscript.

Funding: This research was supported by an Alexander von Humboldt Postdoctoral Fellowship to one author (E.S.S.). The U-Pb isotopic measurements were funded by the German Academic Exchange Service (DAAD, No 57378441) and Stiftung zur Förderung der Edelsteinforschung of Johannes Gutenberg-Universität Mainz (2018). EDXRF analyses, $\mathrm{Rb}-\mathrm{Sr}$ and $\mathrm{Sm}-\mathrm{Nd}$ isotopic measurements were supported by the Vernadsky Institute of Geochemistry and Analytical Chemistry (State Assignment no. 0137-2019-0014).

Acknowledgments: We are grateful to our colleagues from MGRI (Mikhail Yu. Gurvitch), GEOKHI RAS (Lia N. Kogarko, Natalia N. Kononkova, Tatiana G. Kuzmina, Victor A. Turkov), Stefan Buhre (JGU Mainz), colleagues from Heidelberg University (Axel Schmitt, Mario Trieloff and Sonja Storm), Jasper Berndt (Westfälische Wilhelms-Universität Münster), Delia Rösel (TU Bergakademie Freiberg and University of Gothenburg), Natalia P. Gorbunova (Institute of Geology, Academy of Science of Tajikistan) for their help in sample preparations, assistance in analytical measurements and discussions on the topic of research. The authors thank the Editor of Minerals and Guest Editors Frederick Lin Sutherland and Khin Zaw for invitation to submit the manuscript for consideration and possible contribution in a special issue on "Mineralogy and geochemistry of ruby". We are also thankful to Ian Graham (University of New South Wales, Australia) and two anonymous reviewers for improving the text of an earlier version of this article.

Conflicts of Interest: The authors declare no conflict of interest.

\section{References}

1. Graham, I.; Sutherland, F.L.; Zaw, K.; Nechaev, V.; Khanchuk, A. Advances in our understanding of the gem corundum deposits of the West Pacific continental margins intraplate basaltic fields. Ore Geol. Rev. 2008, 34, $200-215$. [CrossRef]

2. Garnier, V.; Giuliani, G.; Ohnenstetter, D.; Fallick, A.E.; Dubessy, J.; Banks, D.; Hoàng Quang, V.; Lhomme, T.; Maluski, H.; Pêcher, A.; et al. Marble-hosted ruby deposits from Central and Southeast Asia: Towards a new genetic model. Ore Geol. Rev. 2008, 34, 169-191. [CrossRef]

3. Stern, R.G.; Tsujimori, T.; Harlow, G.; Groat, L.A. Plate tectonic gemstones. Geology 2013, 41, $723-726$. [CrossRef]

4. Giuliani, G.; Ohnenstetter, D.; Fallick, A.E.; Groat, L.; Fagan, A.G. The geology and genesis of gem corundum deposits. In Geology of Gem Deposits, 2nd ed.; Groat, L.A., Ed.; Mineralogical Association of Canada: Tucson, AZ, USA, 2014; pp. 29-112.

5. Sorokina, E.S.; Rösel, D.; Häger, T.; Mertz-Kraus, R.; Saul, J.M. LA-ICP-MS U-Pb dating of rutile inclusions within corundum (ruby and sapphire): New constraints on the formation of corundum deposits along the Mozambique belt. Miner. Depos. 2017, 52, 641-649. [CrossRef]

6. Saul, J.M. Transparent gemstones and the most recent supercontinent cycle. Int. Geol. Rev. 2017, 60, 889-910. [CrossRef]

7. Meng, F.; Shmelev, V.R.; Kulikova, K.V.; Ren, Y. A red-corundum-bearing vein in the Rai-Iz ultramafic rocks, Polar Urals, Russia: The product of fluid activity in a subduction zone. Lithos 2018, 320, 302-314. [CrossRef]

8. Dmitriev, E.A. Types of corundum mineralization in the Precambrian marbles of the Muzkol-Rangkulsky anticlinorium. In Proceedings on Geology and Prospecting of the Gemstone Deposits of Tajikistan; Klimkin, A.V., Ed.; Donish: Dushanbe, Tajikistan, 1987; pp. 34-36. (In Russian)

9. Dufour, M.S.; Kol'tsov, A.B.; Zolotarev, A.A.; Kuznetsov, A.B. Corundum-bearing metasomatic rocks in the Central Pamirs. Petrology 2007, 15, 151-167. [CrossRef] 
10. Barnov, N.G. Geological Conditions of Localization and Prerequisites for Industrial Mineralization of Ruby in Marbles Using the Example of the Snezhnoye Deposit (Central Pamir). Unpublished Ph.D. Thesis, MGRI, Moscow, Russia, 2010. (In Russian).

11. Sorokina, E.S. Ontogeny and Quality of Gem Ruby from the Deposits of Central and South-East Asia. Unpublished Ph.D. Thesis, Fedorovsky All-Russian Research Institute of Mineral Resources, Moscow, Russia, 2011. (In Russian).

12. Nasriddinov, Z.Z. Geological and Mineralogical Features, Determining Quality of Rough from Snezhnoe Deposit. Unpublished Ph.D. Thesis, Russian State Geological Prospecting University, Moscow, Russia, 2013. (In Russian).

13. Barkhatov, B.P. Tectonics of the Pamirs; Leningrad University: Leningrad, USSR, 1963; 240p. (In Russian)

14. Litvinenko, A.K.; Nasreddinov, Z.Z.; Sorokina, E.S. Margarite-Rock-forming mineral from Snezhnoe ruby deposit, Central Pamir. Proc. High. Educ. Establ. Geol. Explor. 2015, 4, 80-82. (In Russian)

15. Sorokina, E.S.; Litvinenko, A.K.; Hofmeister, W.; Häger, T.; Jacob, D.E.; Nasriddinov, Z.Z. Rubies and Sapphires from Snezhnoe, Tajikistan. Gems Gemmol. 2015, 51, 160-175. [CrossRef]

16. Baratov, R.B. Dismemberment of Stratified and Intrusive Rocks of Tajikistan; Donish: Dushanbe, Tajikistan, 1976; 268p. (In Russian)

17. Budanov, V.I.; Budanova, K.T. Geological and petrological characteristics of the exposed crystalline basement. In The Earth's Crust and the Upper Mantle of Tajikistan; Donish: Dushanbe, Tajikistan, 1993; 275p. (In Russian)

18. Dufour, M.S.; Popova, V.A.; Krivets, T.N. Alpine Metamorphic Complex of the Eastern Part of the Central Pamirs; Leningrad University: Saint Petersburg, Russia, 1970; 126p.

19. Budanova, K.T. Metamorphic Formations of Tajikistan; Donish: Dushanbe, Tajikistan, 1991; 336p. (In Russian)

20. Litvinenko, A.K. Geology of Snezhnoe Ruby Deposit, Central Pamirs; Gornaya kniga: Moscow, Russia, 2020; 103p. (In Russian)

21. Jochum, K.P.; Nohl, U.; Herwig, K.; Lammel, E.; Stoll, B.; Hofmann, A.W. GeoReM: A new geochemical database for reference materials and isotopic standards. Geostand. Geoanal. Res. 2005, 29, 333-338. [CrossRef]

22. Jochum, K.P.; Weis, U.; Stoll, B.; Kuzmin, D.; Yang, Q.; Raczek, I.; Jacob, D.E.; Stracke, A.; Birbaum, K.; Frick, D.A.; et al. Determination of reference values for NIST SRM 610-617 glasses following ISO Guidelines. Geostand. Geoanal. Res. 2011, 35, 397-429. [CrossRef]

23. Luvizotto, G.; Zack, T.; Meyer, H.P.; Ludwig, T.; Triebold, S.; Kronz, A.; Münker, C.; Stockli, D.; Prowatke, S.; Klemme, S.; et al. Rutile crystals as potential trace element and isotope mineral standards for microanalysis. Chem. Geol. 2009, 261, 346-369. [CrossRef]

24. Axelsson, E.; Pape, J.; Berndt, J.; Corfu, F.; Mezger, K.; Raith, M.M. Rutile R632-A new natural reference material for U-Pb and $\mathrm{Zr}$ determination. Geostand. Geoanal. Res. 2018, 42, 319-338. [CrossRef]

25. Kooijman, E.; Berndt, J.; Mezger, K. U-Pb dating of zircon by laser ablation ICP-MS: Recent improvements and new insights. Eur. J. Miner. 2012, 24, 5-21. [CrossRef]

26. Mezger, K.; Hanson, G.N.; Bohlen, S.R. High-precision U-Pb ages of metamorphic rutile: Application to the cooling history of high-grade terranes. Earth Planet. Sci. Lett. 1989, 96, 106-118. [CrossRef]

27. Ludwig, K.R. A User's Manual; Berkeley Geochronology Center: Berkeley, CA, USA, 2009; p. 100.

28. Wanthanachaisaeng, B.; Häger, T.; Hofmeister, W.; Nasdala, L. Raman-und fluoreszenz-spektroskopische Eigenschaften von Zirkon-Einschlüssen in chrom-haltigen Korunden aus Ilakaka und deren Veränderung durch Hitzebehandlung. Z Dt. Gemmol. Ges. 2006, 55, 119-131. (In German)

29. Mariga, J.; Ripley, E.M.; Li, C.; McKeegan, K.D.; Schmidt, A.; Groove, M. Oxygen isotopic disequilibrium in plagioclase-corundum-hercynite xenoliths from the Voisey's Bay Intrusion, Labrador, Canada. Earth Planet. Sci. Lett. 2006, 248, 263-275. [CrossRef]

30. Sorokina, E.S.; Ozhogina, E.G.; Jacob, D.E.; Hofmeister, W. Some features of corundum ontogeny and the quality of ruby from Snezhnoe deposit, Tajikistan (the Eastern Pamirs). Zapiski RMO (Proc. Russ. Mineral. Soc.) 2012, 141, 100-108. (In Russian)

31. Sorokina, E.S.; Hofmeister, W.; Häger, T.; Mertz-Kraus, R.; Buhre, S.; Saul, J.M. Morphological and chemical evolution of corundum (ruby and sapphire): Crystal ontogeny reconstructed by EMPA, LA-ICP-MS, and Cr3+ Raman mapping. Am. Mineral. 2016, 101, 2716-2722. [CrossRef]

32. Peucat, J.J.; Ruffault, P.; Fritch, E.; Bouhnik-Le-Coz, M.; Simonet, C.; Lasnier, B. Ga/Mg ratio as a new geochemical tool to differentiate magmatic from metamorphic blue sapphires. Lithos 2007, 98, 261-274. [CrossRef] 
33. Sutherland, F.L.; Abduriyim, A. Geographic typing of gem corundum: A test case from Australia. J. Gemmol. 2009, 31, 203-210. [CrossRef]

34. Giuliani, G.; Caumon, G.; Rakotosamizanany, S.; Ohnenstetter, D.; Rakototondrazafy, M. Classification chimique des corindons par analyse factorielle discriminante: Application à la typologie des gisements de rubis et saphirs. Rev. Gemmol. 2014, 188, 14-22.

35. Giuliani, G.; Fallick, A.E.; Garnier, V.; France-Lanord, C.; Ohnenstetter, D.; Schwarz, D. Oxygen isotope composition as a tracer for the origins of rubies and sapphires. Geology 2005, 33, 249-252. [CrossRef]

36. Yaroshevsky, A.A. Abundances of chemical elements in the Earth's crust. Geochem. Int. 2006, 44, 48-55. [CrossRef]

37. Kostitsyn, Y.A.; Belousova, E.A.; Silant'ev, S.A.; Bortnikov, N.S.; Anosova, M.O. Modern problems of geochemical and U-Pb geochronological studies of zircon in oceanic rocks. Geochem. Int. 2005, 53, 759-785. [CrossRef]

38. Zack, T.; Moraes, R.; Kronz, A. Temperature dependence of Zr in rutile: Empirical calibration of a rutile thermometer. Contrib. Mineral. Petrol. 2004, 148, 471-488. [CrossRef]

39. Watson, E.B.; Wark, D.A.; Thomas, J.B. Crystallization thermometers for zircon and rutile. Contrib. Mineral. Petrol. 2006, 151, 413-433. [CrossRef]

40. Kievlenko, E.Y. Geology of Gems; Soregaroli, A., Ed.; Ocean Pictures Ltd.: Littleton, CO, USA, 2003; 432p.

41. Dmitriev, E.A.; Ishan-Sho, G.A. Chromium-bearing muscovites in metamorphic and hydrothermal formations of the Pamirs. Zapiski VMO (Proc. All-Union Mineral. Soc.) 1987, 116, 690-697. (In Russian)

42. Terekhov, E.N.; Akimov, A.P. Tectonic setting and genesis of the gem corundum deposits of High Azia. Lithosphere 2013, 5, 122-140. (In Russian)

43. Rossovskiy, L.N.; Konovalenko, S.I.; Ananjev, S.A. Conditions of ruby formation in marbles. Geol. Rudn. Mestorozhd. 1982, 24, 57-66. (In Russian)

44. Rossovsky, L.N. Ruby and sapphire deposits of the Alpine-Himalayan fold belt and their formation conditions. In Proceedings on Geology and Prospecting of Gemstone Deposits in Tajikistan; Klimkin, A.V., Ed.; Donish: Dushanbe, Tajikistan, 1987; pp. 36-38. (In Russian)

45. Litvinenko, A.K. Nuristan-South Pamir province of Precambrian gems. Geol. Ore Deposit. 2004, 46, $263-268$.

46. Litvinenko, A.K. The reconstruction of bauxite-like sediments in the Early Proterozoic metamorphites of the Central Pamir. In Proceedings of the Materials of the 5th All-Russian Lithologic Conference "the Types of Sedimentogenesis and Lithogenesis and Their Evolution in the History of the Earth", Ekaterinburg, Russia, 14-16 October 2008; pp. 428-430. (In Russian).

47. Predovsky, A.A. Reconstruction of Conditions of Sedimentogenesis and Volcanism of Early Precambrian; Nauka: Leningrad, USSR, 1980; 152p. (In Russian)

48. Golovenok, V.K. High-Alumina Precambrian Formations; Nedra: Leningrad, USSR, 1977; 267p. (In Russian)

49. Budanova, K.T. Mineralogical and petrochemical characteristics of high-alumina rocks in the eastern part of Central Pamir. Proc. AS Repub. Tajikistan (Zap. AN Resp. Tadjikistan). 1993, 1, 26-33. (In Russian)

50. Giuliani, G.; Fallick, A.E.; Rakotondrazafy, A.F.M.; Ohnenstetter, D.; Andriamamonjy, A.; Rakotosamizanany, S.; Ralantoarison, T.; Razanatseheno, M.M.; Dunaigre, C.; Schwarz, D. Oxygen isotope systematics of gem corundum deposits in Madagascar: Relevance for their geological origin. Miner. Deposita 2007, 42, 251. [CrossRef]

51. Ferry, J.M.; Watson, E.B. New thermodynamic models and revised calibrations for the Ti-in-zircon and Zr-in-rutile thermometers. Contrib. Mineral. Petrol. 2007, 154, 429-437. [CrossRef]

52. Bohlen, S.; Montana, A.; Kerrick, D.M. Precise determination of the equilibria kyanite=sillimanite and kyanite=andalusite and a revised triple point for $\mathrm{Al}_{2} \mathrm{SiO}_{5}$ polymorphs. Am. Mineral. 1991, 76, 677-680.

53. Phyo, M.M.; Wang, H.A.; Guillong, M.; Berger, A.; Franz, L.; Balmer, W.A.; Krzemnicki, M.S. U-Pb Dating of Zircon and Zirconolite Inclusions in Marble-Hosted Gem-Quality Ruby and Spinel from Mogok, Myanmar. Minerals 2020, 10, 195. [CrossRef]

54. Mattauer, M.; Matte, P.; Jolivet, J.L. A 3D model of the India-Asia collision at late scale. Comptes Rendus 1999, 328, 499-508.

(C) 2020 by the authors. Licensee MDPI, Basel, Switzerland. This article is an open access article distributed under the terms and conditions of the Creative Commons Attribution (CC BY) license (http://creativecommons.org/licenses/by/4.0/). 